\title{
LITHOSTRATIGRAPHY OF THE EARLY PROTEROZOIC KAINUU SCHIST BELT IN THE KURKIKYLÄ-SIIKAVAARA AREA, NORTHERN FINLAND, WITH EMPHASIS ON THE GENETIC APPROACH
}

\author{
KAUKO LAAJOKI, KARI STRAND and PAAVO HÄRMÄ
}

LAAJOKI, K., STRAND, K. and HÄRMÄ, P., 1989. Lithostratigraphy of the early Proterozoic Kainuu Schist Belt in the Kurkikylä-Siikavaara area, northern Finland, with emphasis on the genetic approach. Bull. Geol. Soc. Finland 61, Part 1, 65-93.

The early Proterozoic (Karelian) supracrustal formations of the northeastern part of the Kainuu Schist Belt in the Kurkikylä-Siikavaara area in northern Finland are formally classified into the Kurkikylä, Korvuanjoki and East Puolanka Groups.

The Kurkikylä Group (400-700 m) represents a continental rift stage on the late Archaean cratonic basement and consists of two interfingering formations of immature conglomerates, diamictites and sandstones of alluvial fan and braided river origin. One of these terminates in the fine-grained rocks of a lacustrine basin associated with subaqueous mass flows and some oversized clasts suggesting glacially influenced deposition for this later stage. Active rifting is indicated by one formation with superimposed subaerial lava flows.

The Korvuanjoki Group (600-1200 m), separated by a chemical weathering crust from the Kurkikylä Group, consists of two formations of quartz pebble conglomerates and mature sandstones of braided alluvial plains suggesting deposition in half-grabens still in a cratonal setting. The group was produced by the reactivation of earlier rift faults in phases of crustal extension and corresponds to the incipient ocean/inland basin stage in the development of a continental margin before complete crustal breakup.

The East Puolanka Group (2300-2600 m) was deposited unconformably on the Korvuanjoki Group and consists of six quartzitic formations with minor finegrained rocks and one formation of volcanics, predominantly subaerial lavas. The group represents deposition on the proximal parts of a platformal shelf exhibiting records of three transitions from a fluvial to a shallow marine environment. The group belongs to the lower part of a large opening clastic wedge on a divergent continental margin which, in these early stages, was repeatedly rifted, as indicated by sporadic volcanism and the intrusion of diabases.

Key words: metasedimentary rocks, metavolcanic rocks, deposition, tectonics, lithostratigraphy, Proterozoic, Kurkikylä, Korvuanjoki, Puolanka, Finland.

K. Laajoki, K. Strand and P. Härmä*: Department of Geology, University of Oulu, Linnanmaa, SF-90570 Oulu, Finland.

(* present address: Air-Ix Oy, PL 453, SF-33101 Tampere, Finland)

\section{Introduction}

This paper establishes the formal lithostratigraphic units for the Karelian formations of the northeastern part of the Kainuu Schist Belt in northern Finland. The Kainuu Schist Belt is one of the early Proterozoic (Karelian) schist areas in Finland consisting of metasediments and 


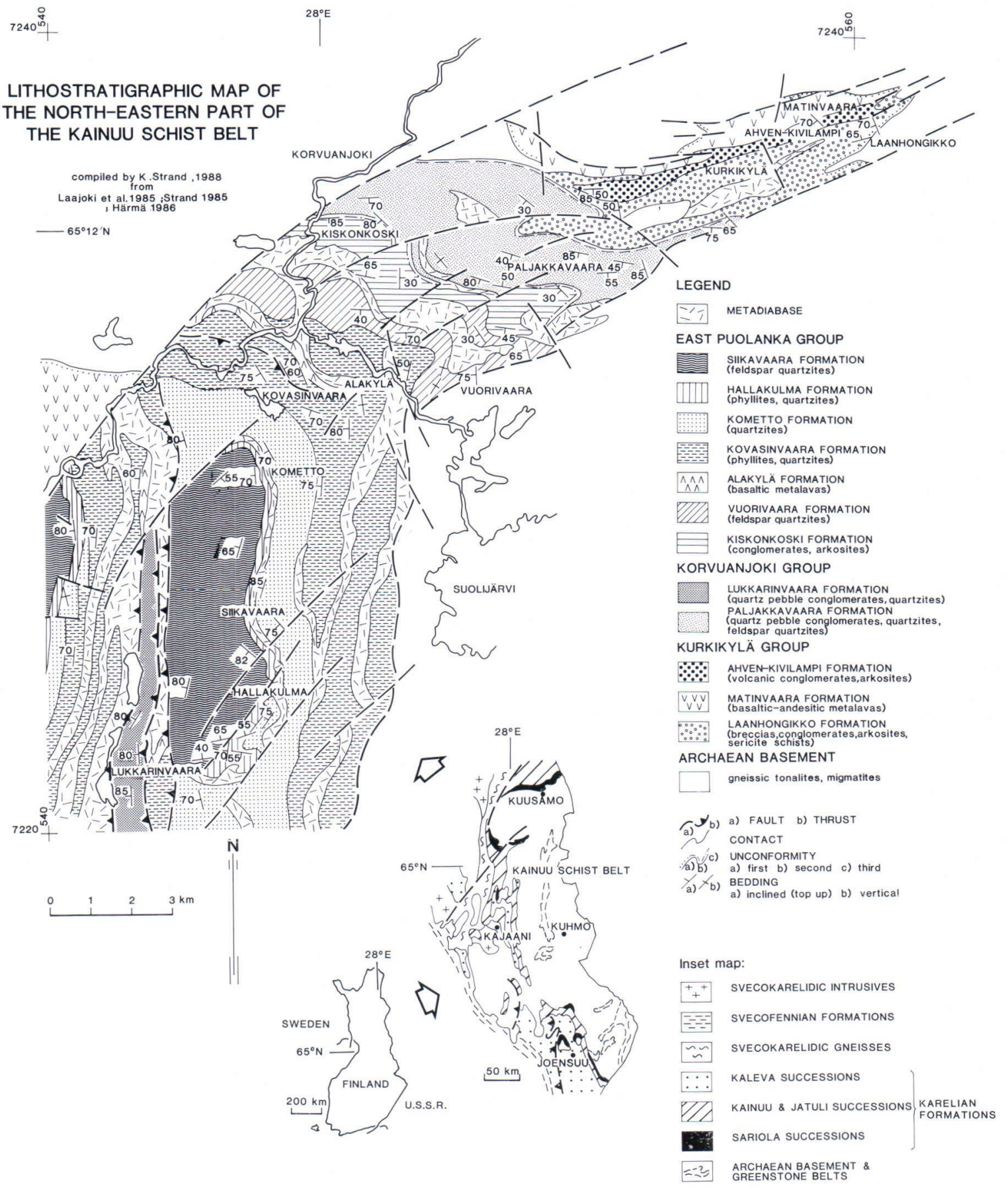

Fig. 1. Lithostratigraphic map of the northeastern part of the Kainuu Schist Belt and its location in a generalized geological map (after Simonen 1980) of the central part of Finland. 
metavolcanics deposited on the late Archaean basement (Fig. 1).

The present results are based on work conducted by the authors in the study area between 1982 and 1984 and partly continued by K. Strand in 1987-1988. The area was mapped by K. Laajoki, P. Ervamaa and H. Idman in connection with the exploration carried out by the Geological Survey of Finland in 1970-1975 and their results were at our disposal. The western and eastern parts of the study area belong to the general geological map sheets (1:400 000) of Oulu-Tornio (Enkovaara et al. 1953) and Suomussalmi (Matisto 1958), respectively. The earliest stratigraphic frames for the study area were presented by Väyrynen $(1928,1933,1954)$.

We hope that this paper will encourage workers on the early Proterozoic formations of the Fennoscandian Shield to establish a formal stratigraphy for scientific and exploration purposes (cf. Siedlecka et al. 1985; Laajoki \& Luukas 1988). This would provide a better basis for understanding of Precambrian genetic processes and tectonic styles. It is recommended (e.g. Miall 1984) that the establishment of such a stratigraphy be carried out by persons with a sedimentological training, so that the depositional system concepts can be incorporated into the work.

\section{Establishment of a formal lithostratigraphic unit}

The present trend in the study of stratigraphy is to take a genetic approach in which established and correlated sequences are interpreted in terms of depositional systems, using sedimentological facies analysis and basin mapping methods (e.g. Miall 1984; Galloway 1989). Depositional systems are generally bounded by unconformities or by facies transitions into adjacent, genetically unrelated systems. Within each depositional system it should then be possible to recognize units of formation rank on the basis of genetic criteria.

We apply this genetic approach (see closer Miall 1984, pp. 2-5) and the units are named following the practices and procedures given in the International Stratigraphic Guide (Hedberg 1976) and in the North American Stratigraphic Code published by the North American Comission on Stratigraphic Nomenclature (1983). Useful guidelines are also proposed by Van Eysinga (1970). To give a geographical names to the established units is preferred so that the location or areal extent of a unit in question is easily comprehended and to make scientific discussion clearer and more simple. The conventional hierarchy of lithostratigraphic units (Hedberg 1976) is applied:

Group

\section{Formation}

\section{Member}

\section{Bed or Flow}

A formation is used as a fundamental mappable lithostratigraphic unit. All other lithostratigraphic units are based on the formation. A group is applied to two or more formations which form a lithologically and genetically logical sequence. Our groups are separated from each other by major unconformities. Sedimentological reasons demand that most of our formations are divided into two or more members. The designation of a bed or a unit of beds as a formal unit is generally limited to just those distinctive beds whose recognition is particularly useful. In this paper the formations are described and established under the following captions:

1. Type area and section;

2. Contacts and thickness;

3. Subdivision and lithology

4. Depositional or eruptive setting;

In addition, the exact locality of the type areas and sections and the possible reference sections of the formations, members and beds are given in Appendix 1. To save space the members or the beds are not defined as throughly as the formations. Many of the units described, have been treated or named in some earlier publications, but none of them have previously been established as rigorously as recommended by the international guides referred to above. For this reason all units are considered as being defined formally for 


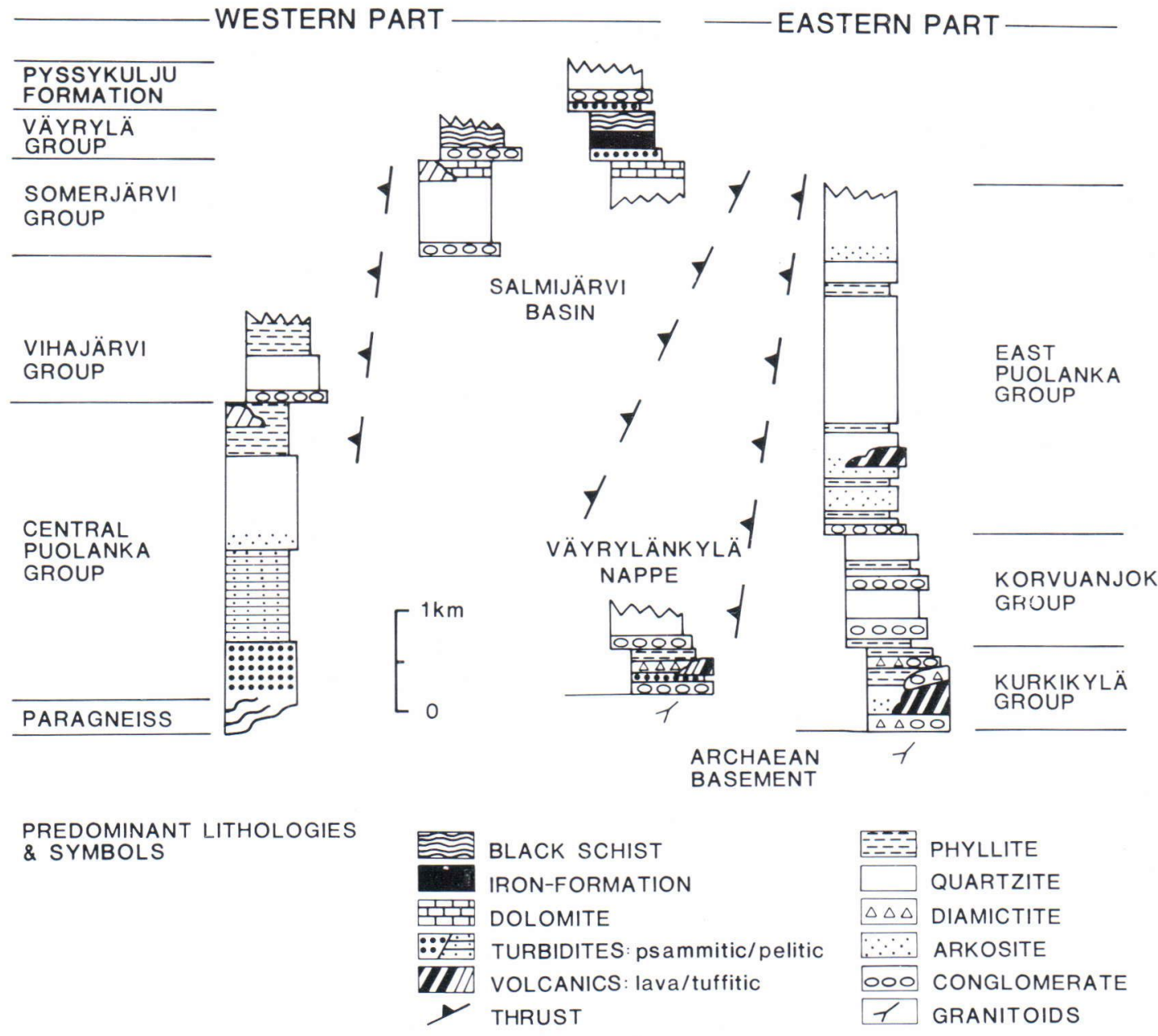

Fig. 2. Generalized lithostratigraphy of the northern part of the Kainuu Schist Belt showing the relative positions of the Karelian formations treated in this paper (modified after Laajoki et al. 1983 and Laajoki 1988b).

the first time in this paper. The publication where the unit in question was first treated is given in parentheses after each captions.

All the rocks of the study area are metamorphosed but, because genetic aspects are emphasized in this paper, the rocks are treated with their primary names.

\section{Regional geological setting}

The study area is located within the communes of Suomussalmi, Puolanka and Pudasjärvi in northern Finland comprising the northeastern corner of the early Proterozoic Kainuu Schist Belt. This belt is about $220 \mathrm{~km}$ long, runs in north-south direction and is pressed in a complex way between two late Archaean basement blocks (for more details see e.g. Laajoki et al. 1983; Laajoki 1986b).

The northern part of the Kainuu Schist Belt comprises the following major units (Fig. 2): The formations of the eastern margin are allochthonous or parallochthonous and they consist of (1) the Kurkikylä Group of Sariola-type immature conglomerates, diamictites and sand- 
Table 1. The lithostratigraphy of the early Proterozoic Kainuu Schist Belt in the Kurkikylä-Siikavaara area.

\section{East Puolanka Group:}

\begin{tabular}{|c|c|}
\hline Siikavaara Fm & \\
\hline \multirow{2}{*}{ Hallakulma Fm } & Pentinsuo $\mathrm{Mb}$ \\
\hline & Nuottilampi Mb \\
\hline \multicolumn{2}{|l|}{ Kometto Fm } \\
\hline \multirow{3}{*}{ Kovasinvaara Fm } & Pikku-Äikkä Mb \\
\hline & Korpijoki Mb \\
\hline & Reikä-Äikkä Mb \\
\hline \multicolumn{2}{|l|}{ Alakylä Fm } \\
\hline \multicolumn{2}{|l|}{ Vuorivaara Fm } \\
\hline \multirow{2}{*}{ Kiskonkoski Fm } & Paljakkaoja Mb \\
\hline & $\begin{array}{l}\text { Nenäkangas Mb } \\
\text { Jylkynsuo Bed }\end{array}$ \\
\hline
\end{tabular}

- unconformity -

\section{Korvuanjoki Group:}

\begin{tabular}{|c|c|c|c|}
\hline \multirow{3}{*}{ Paljakkavaara Fm } & Honka-Jylkky Mb & \multirow{2}{*}{ Lukkarinvaara Fm } & Iso-Lukkari Mb \\
\hline & Pöksäkallio Mb & & Kivisuo $\mathrm{Mb}$ \\
\hline & $\begin{array}{l}\text { Kurkisuo Mb } \\
\text { Paljakantie Beds }\end{array}$ & & \\
\hline
\end{tabular}

Kurkikylä Group:

\begin{tabular}{|c|c|c|c|}
\hline \multirow{4}{*}{ Laanhongikko Fm } & Kaaperinsuo $\mathrm{Mb}$ & & \\
\hline & Rytiloma Mb & \multirow{2}{*}{ Ahven-Kivilampi Fm } & Kalettomansuo Mb \\
\hline & Kivipuro Mb & & Havukkasuo Mb \\
\hline & Hetehongikko Mb & Matinvaara Fm & \\
\hline
\end{tabular}

\section{Archaean basement}

stones and Sumi-type metalavas, which occur only in the very north; (2) the Korvuanjoki Group of the Paljakkavaara and Jaurakka areas which represents the first quartz arenitic sequence that overlies the Kurkikylä Group; and (3) the East Puolanka Group which consists of relatively ma- 


\section{KURKIKYLÄ GROUP}

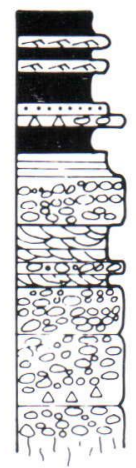

Kaaperinsuo

$\mathrm{Mbr}$

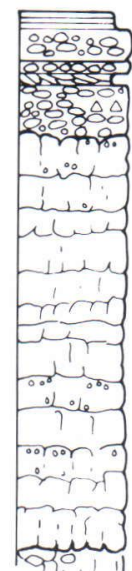

Kalettomansuo

Mbr

Havukkasuo

AHVEN-KIVILAMPI

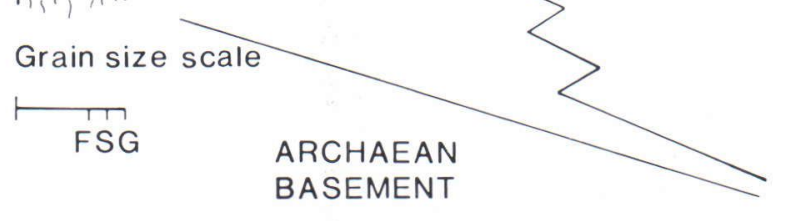

Rytiloma

$\mathrm{Mbr}$

Kivipuro

Mbr

Hetehongikko

$\mathrm{Mbr}$

FM

A

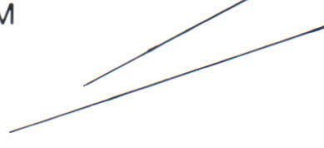

(1)

\section{LEGEND}

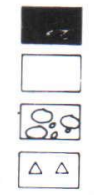

Mbr FM

Mor

Superimposed MATINVAARA lava flows FM

Fig. 3. Combined type sections with average thicknesses and relative positions of the formations of the Kurkikylä Group.

ture Jatuli-type successions of sandstones which can be followed along the whole eastern margin of the Kainuu Schist Belt. The uppermost parts of the last group have been cut off by thrusts, as indicated e.g. by the Väyrylänkylä Nappe (Laajoki 1973, 1980b, 1988a; Laajoki et al. 1983; Strand 1988). The formations of the western margin of the belt are folded and thrusted in a complex way and they cannot be readily correlated with those of the eastern margin. Farthest to the west occur (1) paragneisses, at West Puolanka and north of Lake Oulujärvi, most of which represent highly metamorphosed Karelian rocks. Eastwards the gneisses gradually grade into (2) the Central Puolanka Group (Laajoki 1986a; Laajoki \& Korkiakoski 1988) which is overlain unconformably by two successive transgressive sedimentary units, (3) the Vihajärvi Group and (4) the Somerjärvi Group (Kangas 1985), of which the latter resembles much the upper part of the East Puolanka Group. The Somerjärvi Group is overlain in the Salmijärvi Basin by (5) the Väyrylä Group with Kaleva-type successions of turbidites, black schists and iron-formations. The topmost unit is (6) the Pyssykulju Formation (Laajoki 1988a).

This paper establishes the formal lithostratigraphy of the relatively allochthonous eastern margin of the Kainuu Schist Belt in the Kurkikylä-Siikavaara area. The defined and formally named units are presented in Table 1.

\section{Kurkikylä Group (Laajoki 1980a, p.4)}

\section{Definition}

Name and subdivision: The Kurkikylä Group includes the formations deposited on the late Ar- 

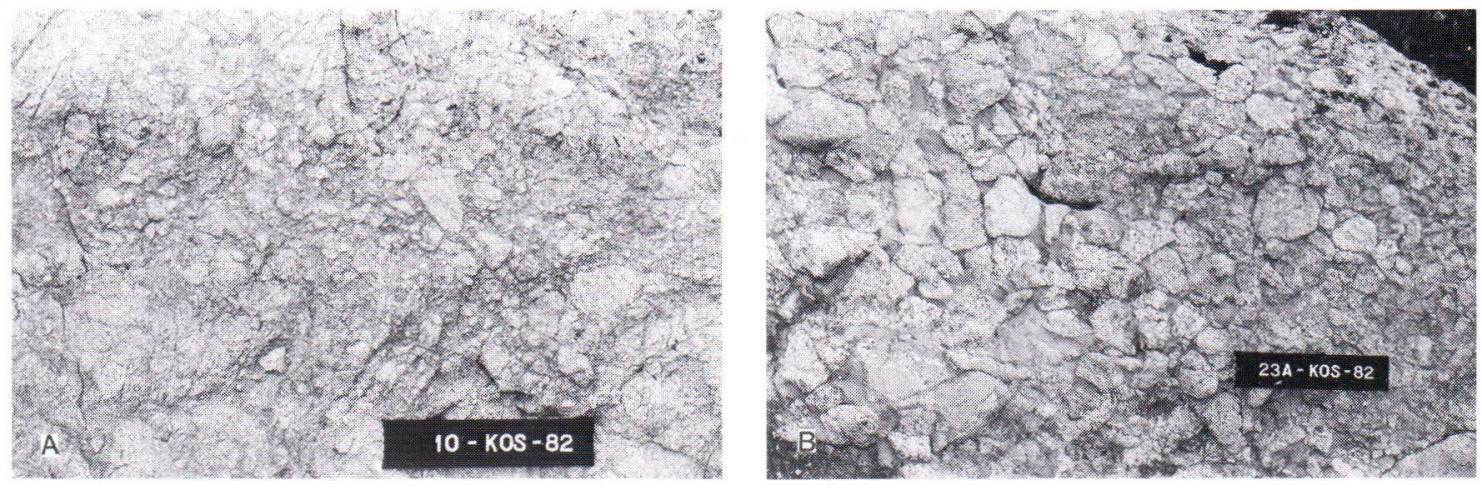

Fig. 4. Two predominant types of conglomerate of the Hetehongikko Member of the Laanhongikko Formation. A. Massive basal breccia above the nonconformity. B. Matrix-supported conglomerate infiltrated by a small amount of fine sandy to silty matrix. Angular clasts are predominantly tonalitic. Label $16.5 \mathrm{~cm}$. Photos K. Strand.

chaean basement and overlain by the Korvuanjoki Group in the northeastern corner of the Kainuu Schist Belt. It is named after the Kurkikylä village in Suomussalmi (Laajoki 1980a) and comprises, in the study area, three interfingering formations (Table 1; Fig. 3): (1) the Laanhongikko Formation; (2) the Matinvaara Formation; and (3) the Ahven-Kivilampi Formation. The group was established by Laajoki (1980a) but was later studied in detail by Strand $(1985,1988)$. Some of its rock types were described by Enkovaara et al. (1953) and Matisto (1958). We also include in this group the conglomerates and volcanics which occur as a counterpart in the Jaurakka area (see Meriläinen 1977).

Age: $\mathrm{Pb}-\mathrm{Pb}$ dating by M. Sakko gives an age of $2271+-93$ Ma to the metalavas of the Matinvaara Formation (Announcement of the Branch of Isotope Geology of the Geological Survey of Finland 1983).

\section{Laanhongikko Formation (Laajoki 1980a,} p.4, renamed by Laajoki et al. 1983, p.43)

Type area and section: The Laanhongikko Formation is well exposed in the Laanhongikko area in the northeastern part of Kurkikylä. The type section is situated in this area but for the upper parts of the formation additional sections are located in the southwestern parts of Kurkikylä.
Contacts and thickness: The lower boundary is a nonconformity with the late Archaean basement. Below the nonconformity a fracture zone $1-2 \mathrm{~m}$ thick occurs overlain by a sequence of massive basal breccias 5-30 m thick (Fig. 4A). The Laanhongikko Formation is unconformably overlain by the Paljakkavaara Formation of the Korvuanjoki Group in the southwest and in the north its lowermost parts are conformably overlain by the Matinvaara Formation. The estimated total thickness of the formation is $300-400 \mathrm{~m}$.

Subdivision and lithology: The Laanhongikko Formation is composed of conglomerates, coarse-grained sandstones and fine-grained rocks with upward fining cyclic lithofacies successions. The formation is subdivided into four members: The lowest is (1) the Hetehongikko Member (new name, displaces Strand's (1985) basal breccia breccia-like conglomerate member) where the basal breccias $(5-30 \mathrm{~m})$ are overlain by a sequence of clast-supported conglomerates 20-50 $m$ thick (Fig 4B) and interbeds of graded diamictites. The angular, mostly tonalitic clasts are up to $30 \mathrm{~cm}$ in diameter. The overlying (2) Kivipuro Member (new name, displaces Strand's (1985) coarse-clastic arkosite member) $(5-80 \mathrm{~m})$ consists of coarse-grained arkosic sandstones with large-scale cross-bedding or horizontal lamination and some gravel interbeds. The conglomeratic (3) Rytiloma Member (new name, displaces 
Strand's (1985) arkose conglomerate member) $(10-100 \mathrm{~m})$ was produced by redeposition of the underlying members. The tonalitic clasts in the conglomerates are more rounded and shale intraclasts have come with them. North from Laanhongikko at Rytiloma it also overlies the AhvenKivilampi Formation. (4) the Kaaperinsuo Member (new name, displaces Strand's (1985) sericite schist - sericite phyllite member) is a succession of fine-grained sandstones and mudstones $80-150 \mathrm{~m}$ thick showing lamination and rippled surfaces. Within these there is a $5-10 \mathrm{~m}$ thick unit of graded matrix-supported conglomerates, diamictites and graded to massive sandstones. The associated fines contain sandy lenses and oversized clasts. The clasts are mainly well rounded gneissic tonalites, though some lava fragments are also found. The fine-grained rocks are free from feldspar clasts, but in some place sericite and carbonate pseudomorphs after plagioclase can be seen. South from Kurkikylä laminated fines contain chloritoid porphyroblasts indicating the aluminous nature of the upper parts of this member.

Depositional setting: The poor sorting and angular clasts of the lower part of the formation suggest a proximal source area. The basal breccias are due to the in situ physical weathering of the underlying tonalites. The Hetehongik ko and the Kivipuro Members are interpreted as deposits of proximal braided streams of alluvial fans (Strand 1985, 1988). The upward fining generally indicates vertical aggradation and gradual abandonment of the fans (Miall 1977). The Rytiloma and the Kaaperinsuo Members represent a distal alluvial environment above the relict fans. Fine-grained rocks of a lacustrine basin associated with some oversized clasts and subaqueous mass flows suggest glacially influenced deposition for this later stage (Strand 1988). The distal alluvial plain and lacustrine system is interpreted as being elongated longitudinally with respect to the basin axis and as being comparable to the situation documented from Devonian alluvial fans by Larsen \& Steel (1978). The system were influenced by intermittant chemical weathering after deposition.

\section{Matinvaara Formation (Laajoki 1980a, p. 4 renamed by Laajoki et al. 1983, p. 43)}

Type area and section: The Matinvaara Formation is named after Matinvaara, a hill north of the Kurkikylä village. The type section with its well-exposed outcrops is located on the southern side of the hill.

Contacts and thickness: A thin layer of breccias and conglomerates of the Laanhongikko Formation occurs under the Matinvaara Formation or the lower boundary may be partly against the Archaean basement. The formation is overlain by the Ahven-Kivilampi Formation and its thickness is up to $300-500 \mathrm{~m}$.

Lithology: The formation consists mainly of massive or amygdaloidal basaltic to andesitic metalavas (Fig. 5) showing microcrystalline to porphyritic textures. The superimposed lava flows, 5-30 $\mathrm{m}$ thick, have preserved their primary features despite the greenschist facies metamorphism. The flows seem to intertongue as compound lavas (cf. Walker 1970). Former cavities and vesicles are now filled mainly by quartz and epidote and in some areas, by carbonate and quartz. The $\mathrm{SiO}_{2}$ content of the lavas indicates a composition of andesitic basalt and andesite whereas the most acidic types are dacites (Table 2 ). The results plotted on an alkali-silica diagram (Fig. 6) demonstrate a subalkaline nature for the lavas. When compared with the trends of predominantly tholeiitic and calc-alkaline rock suites they show higher values of alkalies, especially in low silica types, most probably due to premetamorphic alteration and metamorphism.

Eruptive setting: The volcanic eruptions of the formation were associated with active tensional rifting stages in an intra-cratonic rift basin (Strand 1985, 1988). Basaltic to andesitic lavas erupted through fissures subaerially filling the bottom plains of the basin. The compound lava 
Fig. 5. Amygdaloidal metalava of the Matinvaara Formation with some internal, vesicle-rich concentration fingers. The cavities and vesicles are filled predominantly by quartz and epidote. Label $10.0 \mathrm{~cm}$. Photo K. Laajoki.

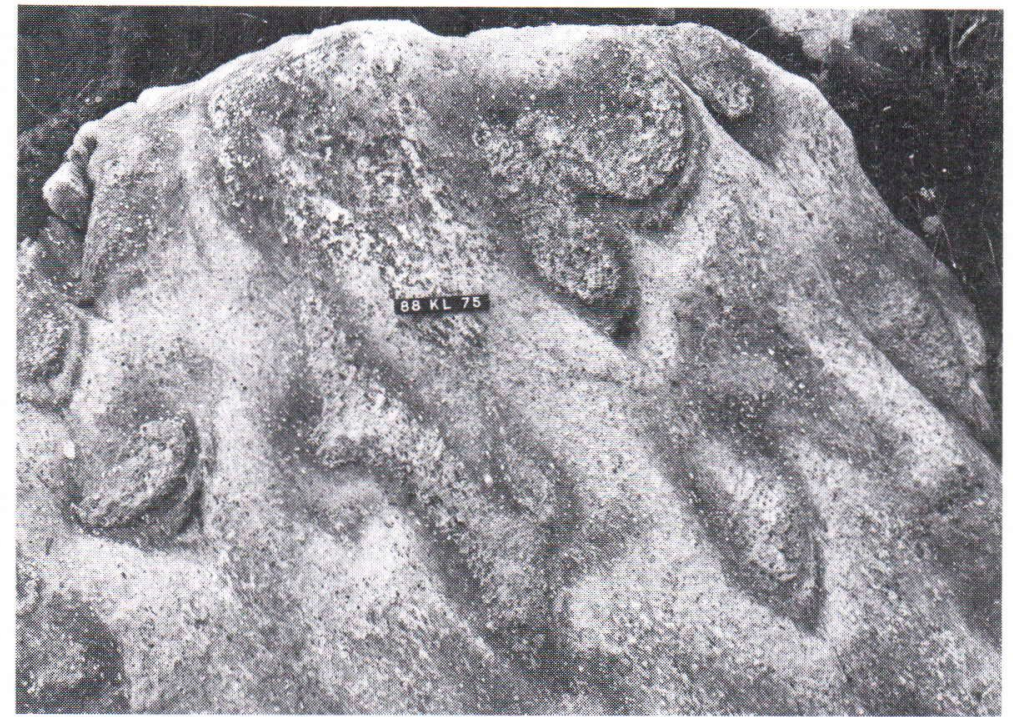

Table 2. Chemical analyses of some metalavas of the Matinvaara Formation. $\mathrm{Fe}_{2} \mathrm{O}_{3} *=$ total iron as $\mathrm{Fe}_{2} \mathrm{O}_{3}$. Samples Nos. 1-2 analysed by XRF at X-Ray Assey Laboratories, Canada and for samples Nos. 3-5 analyst: S. Kaakinen by SRM-18-XRF unit at Department of Geology, University of Oulu.

\begin{tabular}{lccccc}
\hline & 1 & 2 & 3 & 4 & 5 \\
\hline $\mathrm{SiO}_{2} \%$ & 48.4 & 54.1 & 53.7 & 57.1 & 67.7 \\
$\mathrm{TiO}_{2}$ & 2.05 & 0.63 & 0.62 & 0.59 & 0.41 \\
$\mathrm{Al}_{2} \mathrm{O}_{3}$ & 15.5 & 14.3 & 16.2 & 14.6 & 12.2 \\
$\mathrm{Fe}_{2} \mathrm{O}_{3}{ }^{*}$ & 11.7 & 10.3 & 10.1 & 9.3 & 6.8 \\
$\mathrm{MnO}$ & 0.16 & 0.21 & 0.20 & 0.17 & 0.09 \\
$\mathrm{MgO}$ & 2.79 & 6.69 & 7.0 & 5.7 & 3.5 \\
$\mathrm{Cr}_{2} \mathrm{O}_{3}$ & n.d. & n.d. & 0.04 & 0.04 & 0.03 \\
$\mathrm{CaO}$ & 8.70 & 5.34 & 4.50 & 5.93 & 4.10 \\
$\mathrm{Na}_{2} \mathrm{O}$ & 5.00 & 5.34 & 4.3 & 3.8 & 1.7 \\
$\mathrm{~K}_{2} \mathrm{O}$ & 0.36 & 0.34 & 1.47 & 1.12 & 2.46 \\
$\mathrm{BaO}$ & $n . d$. & $n . d$. & 0.04 & 0.02 & 0.07 \\
$\mathrm{P}_{2} \mathrm{O}_{5}$ & 0.29 & 0.00 & 0.01 & 0.11 & 0.00 \\
Ignition loss & 5.62 & 1.70 & 1.50 & 1.12 & 1.18 \\
Total & 100.6 & 99.0 & 99.7 & 99.6 & 100.2 \\
\hline
\end{tabular}
1. $60 \mathrm{E} / \mathrm{KOS}-82$
2. $65 \mathrm{~A} / \mathrm{KOS}-82$
3. $66 \mathrm{~B} / \mathrm{KOS}-82$
4. $65 \mathrm{C} / \mathrm{KOS}-82$
5. $67 \mathrm{C} / \mathrm{KOS}-82$

flows indicate a relatively low effusive rate and that the lavas have piled up quite close to the vent areas (cf. Walker 1970).

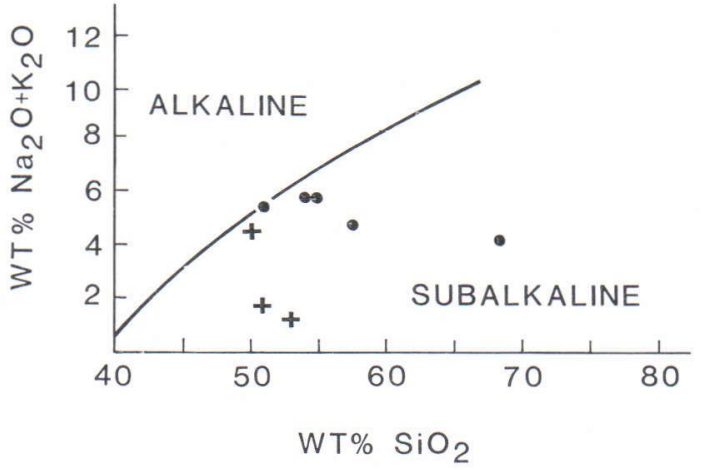

Fig. 6. Alkali-silica diagram for metalavas of the Matinvaara Formation (black dots) of the Kurkikylä Group and the Alakylä Formation (crosses) of the East Puolanka Group. The dividing line is after Irvine \& Baragar (1971).

Ahven-Kivilampi Formation (Laajoki 1980a, p. 4, renamed by Laajoki et al. 1983, p. 43)

Type area and section: The type area is located near the pond Ahven-Kivilampi north of Kurkikylä. The well exposed parts of the formation can be followed northeastwards from AhvenKivilampi. The reference sections for the upper parts of the formation are located southeast of Kurkikylä. 


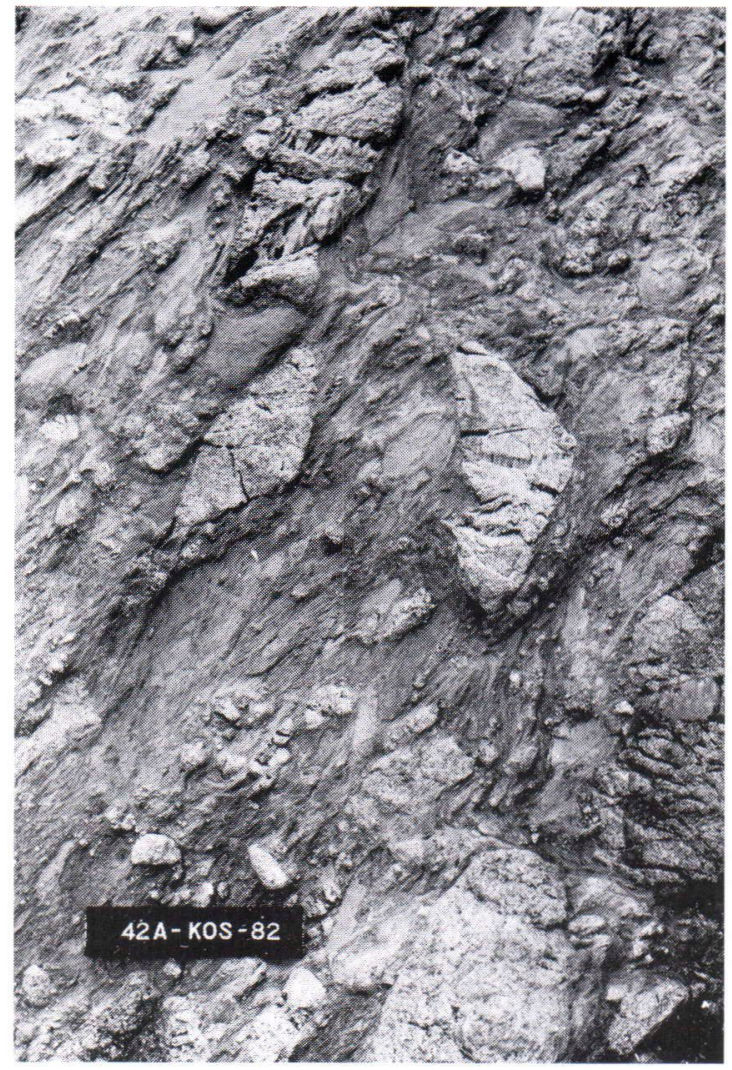

Fig. 7. Diamictitic, partly matrix supported conglomerate of the Havukkasuo Member of the Ahven-Kivilampi Formation. Angular clasts are tonalitic gneisses and lavas and are embedded in a fine, volcaniclastic matrix. Label $16.5 \mathrm{~cm}$. Photo K. Strand.

Contacts and thickness: The lower contact with the underlying Matinvaara Formation is erosional. At its type area the formation also overlies some lowermost parts of the Laanhongikko Formation. In the northeast the upper boundary is against the upper parts of the Laanhongikko Formation elsewhere it is the recent erosion surface. The total thickness of the formation is $50-150 \mathrm{~m}$.

Subdivision and lithology: The formation is composed of volcaniclastic conglomerates and sandstones which are mostly crudely bedded and coarse-grained. The clasts are derived from both the basement and the lavas of the Matinvaara
Formation. The formation is subdivided into two members: (1) the Havukkasuo Member (new name, displaces Strand's (1985) volcanic conglomerate member) consists of diamictitic, poorly sorted conglomerates in which pebble to bouldersized, angular clasts are embedded in a fine, volcaniclastic matrix (Fig. 7). Together with clastsupported variants it forms a succession $10-40$ $m$ thick. In the gravelly portions of (2) the Kalettomansuo Member (new name, displaces Strand's (1985) tuffogenic arkosite - chlorite schist member) the clasts are more rounded than the clasts of the underlying member. The sandstones are coarse-grained, horizontally bedded or low-angle cross-bedded and interbedded with clastsupported conglomerates. Northeastwards from Ahven-Kivilampi this member is represented by a minor portion of fine-grained, chlorite-rich volcaniclastic rocks above the conglomerates of the Havukkasuo Member.

Depositional setting: The Ahven-Kivilampi Formation is interpreted by Strand $(1985,1988)$ as alluvial fans. Some of the lowermost volcaniclastic conglomerates were deposited during active volcanism but the absence of lava interflows and minor tuffs indicates that the bulk of the deposition occurred after main volcanism. The upper parts represent a more transported, separate braided river assemblage redeposited from earlier units. Some thin layers of fine-grained volcaniclastics overlaying the conglomerates in a proximal setting are interpreted as tuffs slightly reworked by surface processes.

\section{Korvuanjoki Group (new name, replaces Laajoki's (1988b) Kainuu Group)}

\section{Definition}

Name and subdivision: This group was originally named the North Kainuu Group (Laajoki 1986b, Fig. 1, shortened to the Kainuu Group in Laajoki 1988b), but because the name Kainuu also has other geological uses we prefer to rename 
this unit as the Korvuanjoki Group. The Korvuanjoki is a river which runs west of Paljakkavaara, the hill where the most typical formation of the group is encountered.

The Korvuanjoki Group is a mature sedimentary unit overlying unconformably the Kurkikylä Group. Its type occurrences at Paljakkavaara were described in detail by Strand $(1985,1988)$. In the study area the group comprises two formations (Table 1; Fig. 8): (1) the Paljakkavaara Formation covering the hills of Paljakkavaara and Honka-Jylkky; and (2) the Lukkarinvaara Formation situated further south as a separate allochthonic unit (Härmä 1986).

Age: Radiometric datings have not been made on the rocks of the group but they are cut by diabase dikes which presumably fall within the age group 2200-2000 Ma. This figure is extrapolated from dikes dated by the U-Pb method on zirkons by O. Kouvo from the Jatuli successions elsewhere (Simonen 1980).

\section{Paljakkavaara Formation (Strand 1985, p. 54)}

Type area and section: The Paljakkavaara Formation is named after the hill on the well exposed northern side of which the type sections of the two lowest members are located. The type areas of the upper parts are on the southern side of the Honka-Jylkky hill near Kiskonkoski and in the Vale-Paljakka area. Some reference sections occur in the Paljakkasuo area, southeast from the Paljakkavaara hill.

Contacts and thickness: The lower boundary of the formation with the Kurkikylä Group is an unconformity and there are relicts of chemically weathered crust between these units. Distal deposits have conformable contacts. The formation is unconformably overlain by the Kiskonkoski Formation of the East Puolanka Group. The thickness of the Paljakkavaara Formation is $800-1200 \mathrm{~m}$.

Subdivision and lithology: The Paljakkkavaara Formation is composed mostly of quartz pebble conglomerates and quartz arenitic sandstones. However, in the upper levels the sandstones display compositions more closely from quartzose arenites to feldspathic arenites (classification by Okada 1971). The formation shows clear upward fining cycles and palaeocurrents to the southwest and west (Fig. 8). A two-tilt correction was necessary for palaeocurrent data to eliminate the predominant plunge of the regional folds and the bed dip (e.g. Potter \& Pettijohn 1977).

The formation is subdivided into three members with gradational contacts: The lowest levels of (1) the Kurkisuo Member (new name, displaces Strand's (1985) sericite quartzite - sericite schist member) are characterised by finegrained rocks but the proximal deposits at Paljakka, and partly at Hallavaara, consist of aluminous conglomerates and sandstones with porphyroblasts of kyanite, andalusite and chloritoid. In matrix-supported conglomerates pebble to cobble-size vein quartz clasts are scattered in a medium to coarse sandy matrix. Those superimposed conglomerate beds in Kettukallio which are 0.2 to $5 \mathrm{~m}$ thick, clast-supported and can be traced laterally for tens to several hundreds of meters are named the Paljakantie Beds (new name, Fig. 9). Some of them contain hematite and ilmenite as heavy minerals which, in some instances, are replaced by pyrite and abundant rutile and leucoxene (Laajoki et al. 1985). The pebbles are rounded vein quartz and the matrix minerals sericite, fine quartz and, in some places, kyanite and pyrophyllite. The sandstones are $100-120 \mathrm{~m}$ in total thickness and medium to very coarse-grained, bimodal and mostly trough cross-bedded. Sandstones of (2) the Pöksäkallio Member (new name, displaces Strand's (1985) coarse-clastic quartzite member) (400-600 m) are mostly coarse-grained and mature containing thin $(10-20 \mathrm{~cm})$ interbeds of gravel. Some of these interbeds are characterized by concentrations of titanium oxides, hematite and metamict zircon (Laajoki et al. 1985). The coarsest sandstones are horizontally laminated. Trough and planar cross-beds are either solitary 


\section{KORVUANJOKI GROUP}
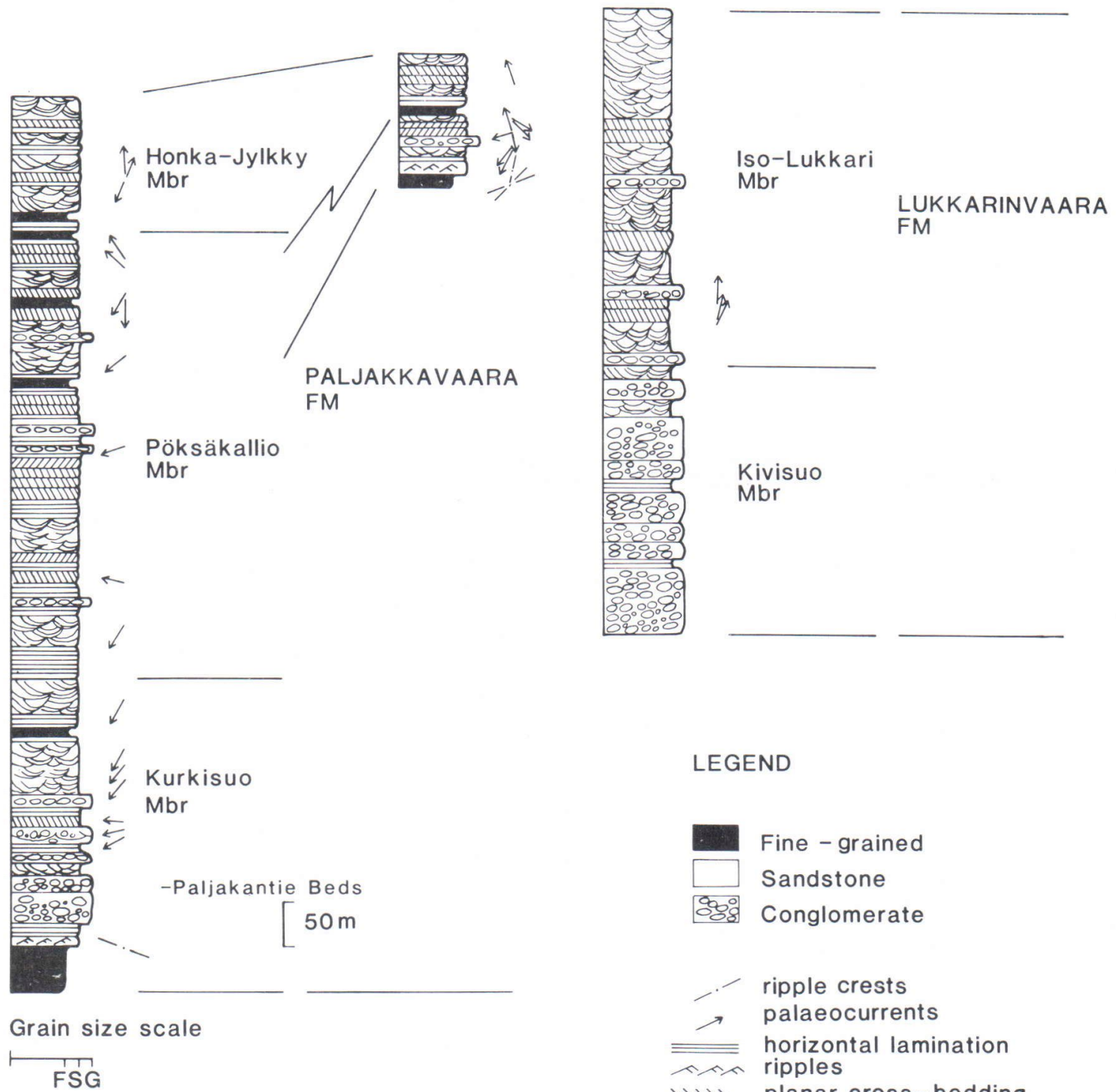

\section{LEGEND}
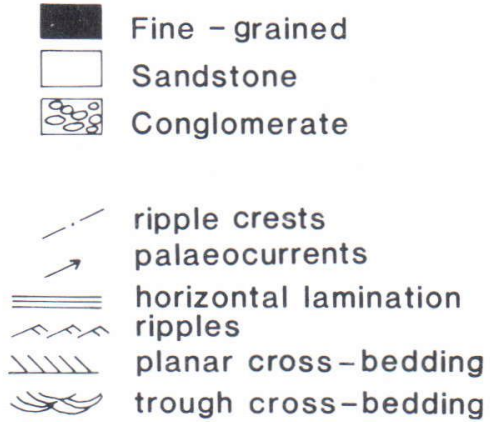

Fig. 8. Combined type sections with average thicknesses and relative positions of the formations of the Korvuanjoki Group in the study area. The reference section for the upper parts of the Paljakkavaara Formation is from the Vale-Paljakka area.

or occur in groups. In the upper part of the member several thin cycles of gravels and planar crossbedded sands are topped by fine-grained rocks. (3) the Honka-Jylkky Member (new name, displaces Strand's (1985) feldspar quartzite member)
(100-150 m) is characterized by the appearance of potassium feldspar among the clasts (Fig. 10).

The matrices of the sandstones and even some feldspar clasts have been replaced by secondary microcrystalline albite $\left(\mathrm{An}_{0-2}\right)$ in many parts of 
Fig. 9. Quartz pebble conglomeratebeds (the Paljakantic Beds) of the Kurkisuo Member of the Paljakkavaara Formation. The sandy matrix contains pyritic concentrations after primary iron oxides. Label $16.5 \mathrm{~cm}$. Photo K. Strand.

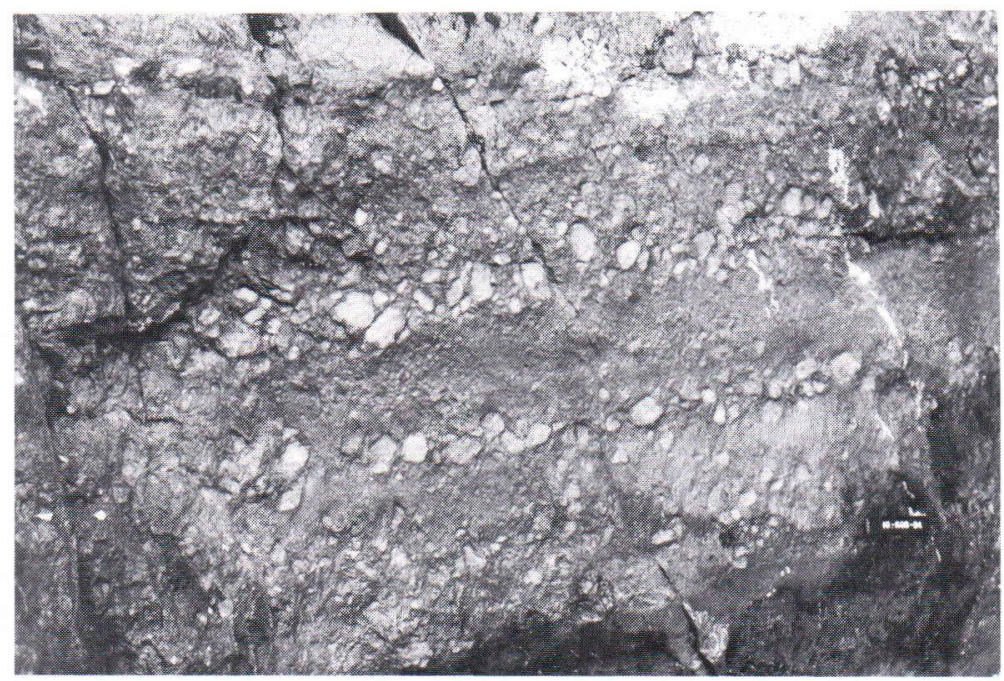

Fig. 10. Grouped trough cross-bedded sets from the sandstones of the HonkaJylkky Member of the Paljakkavaara Formation. The bottoms of the sets have a concentration of coarse feldspar clasts. Label $16.5 \mathrm{~cm}$. Photo K. Strand.

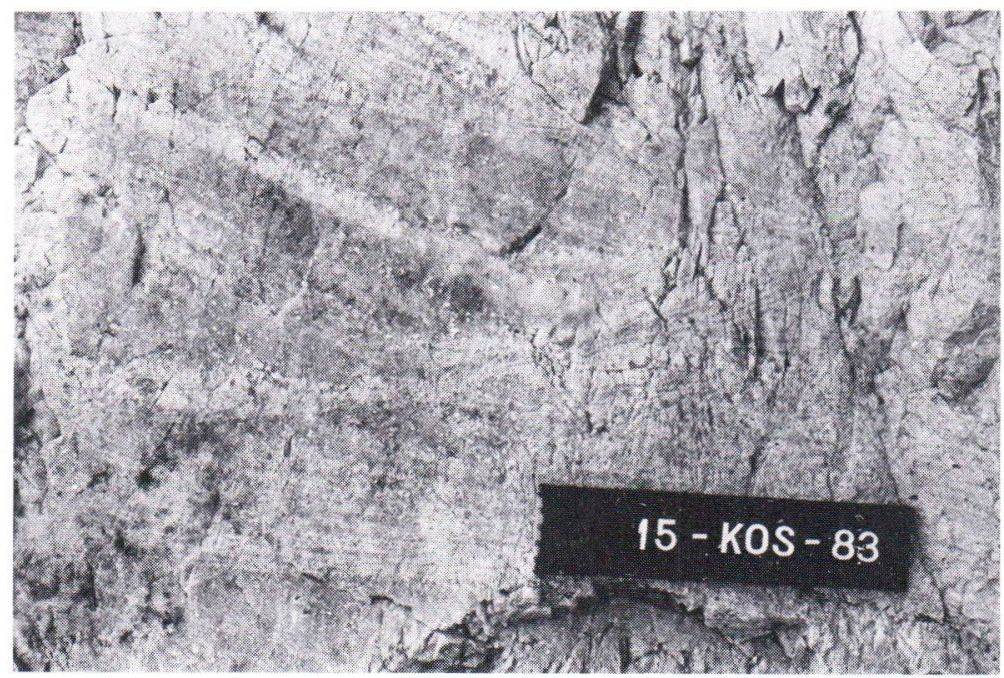

the Honka-Jylkky Member and in the uppermost parts of the Pöksäkallio Member. This type of replacement could have its first occurence during burial diagenesis. The sodium required could have been derived from weathering zones where replacement of sodium rich minerals by clay has effectively occurred and where much sodium was released into the migrating ground water (cf. Schau \& Henderson 1983). Diagenetic mobilization and redistribution of material could then give birth to the present framework (cf. Mack \&
Suttner 1977; Walker 1984). The subsequent metamorphism in the greenschist facies probably only intensified this redistribution.

Depositional setting: The aluminous nature of the lower parts of the formation indicates intense chemical weathering in the source area. The clasticity of the quartz and the lack of any marks of feldspar clasts or their replacement products indicates that the material was already mature before deposition. The Paljakkavaara Formation 
represents deposits of small alluvial fans and braided rivers which were sorting debris into mature gravels and sands near rift faults which remained active (Strand 1985, 1988). Poorly sorted, massive conglomerates with sandy matrices comprise mass flow deposits of heavy floods often redeposited from earlier debris flows. Similar sand-supported conglomerates have been described by Eriksson (1978). The superimposed clast-supported conglomerates represent generally longitudinal bars while the cross-bedded sets are formed mostly by lateral migration of dunes and bars (e.g. Smith 1974; Miall 1977, 1985). The occurrence of detrital potassium feldspar on the top of the thick quartz arenitic succession is intepreted as a partial outworking of the existing weathering crust and as indicating a change in weathering conditions (cf. Basu 1981; James et al. 1981).

\section{Lukkarinvaara Formation (Härmä 1986, p.} 13)

Type area and section: The Lukkarinvaara Formation is named by Härmä (1986) after the hill at the boundary between the parishes of Puolanka and Pudasjärvi. The type section is located on the eastern side of the hill and the uppermost parts of the formation are represented by some well-exposed outcrops on its western and southwestern sides.

Contacts and thickness: The lower boundary with the tectonic wedge of the allochthonous parts of the Alakylä and Kovasinvaara Formations is a thrust (Fig. 1). The upper contact is not exposed. The total thickness of the formation is $600-800 \mathrm{~m}$.

Subdivision and lithology: The formation consists of quartz pebble conglomerates and quartz arenitic sandstones. It is subdivided into two members with a gradational contact in between (Fig. 8): (1) the Kivisuo Member (new name, displaces Härmä's (1986) quartz-pebble conglomerate member) (200-400 m) is gravelly, moderate to poorly sorted. The pebbles are predominantly vein quartz and the matrix minerals sericite, fine quartz and, in some places, abundant hematite. (2) the Iso-Lukkari Member (new name, displaces Härmä's (1986) coarse-clastic quartzite member) (up to $600 \mathrm{~m}$ ) contains pebble and coarse sandstones. They are predominantly trough crossbedded although some planar sets occur with foresets dipping mainly to the north.

Depositional setting: The Lukkarinvaara Formation represents deposits of proximal braided rivers oriented perpendicularly to the nearby reactivated rift faults (Härmä 1986). The source areas were in part weathering zones similar to those of the Paljakkavaara Formation and much of the material was first reworked by fluvial processes before final deposition.

East Puolanka Group (Laajoki 1980a, p. 7, $1980 \mathrm{~b}$, p. 4 , redefined in this study)

\section{Definition}

Name and subdivision: The East Puolanka Group comprises the dominantly quartzitic succession which overlies unconformably the Korvuanjoki Group. Within the study area it is the topmost group, but evidence from other parts of the Kainuu Schist Belt indicates that this group is overlain unconformably by Kaleva-type rocks. It is named by Laajoki (1980a) after its wide distribution in the eastern parts of Puolanka. Originally it also included the rocks now classified in the Korvuanjoki Group and the overfolded western Jatuli-type formations at Puolanka (Laajoki 1980a, p. 10; Kangas 1985), but here we redefine it to comprise only the succession overlying the Korvuanjoki Group in the eastern margin of the belt. Its upper part is cut by thrusts.

The East Puolanka Group is divided into seven superimposed formations listed in stratigraphic order from northeast to southwest as follows (Table 1; Fig. 11): (1) the Kiskonkoski Formation unconformly overlying the Paljakkavaara 
EAST PUOLANKA GROUP

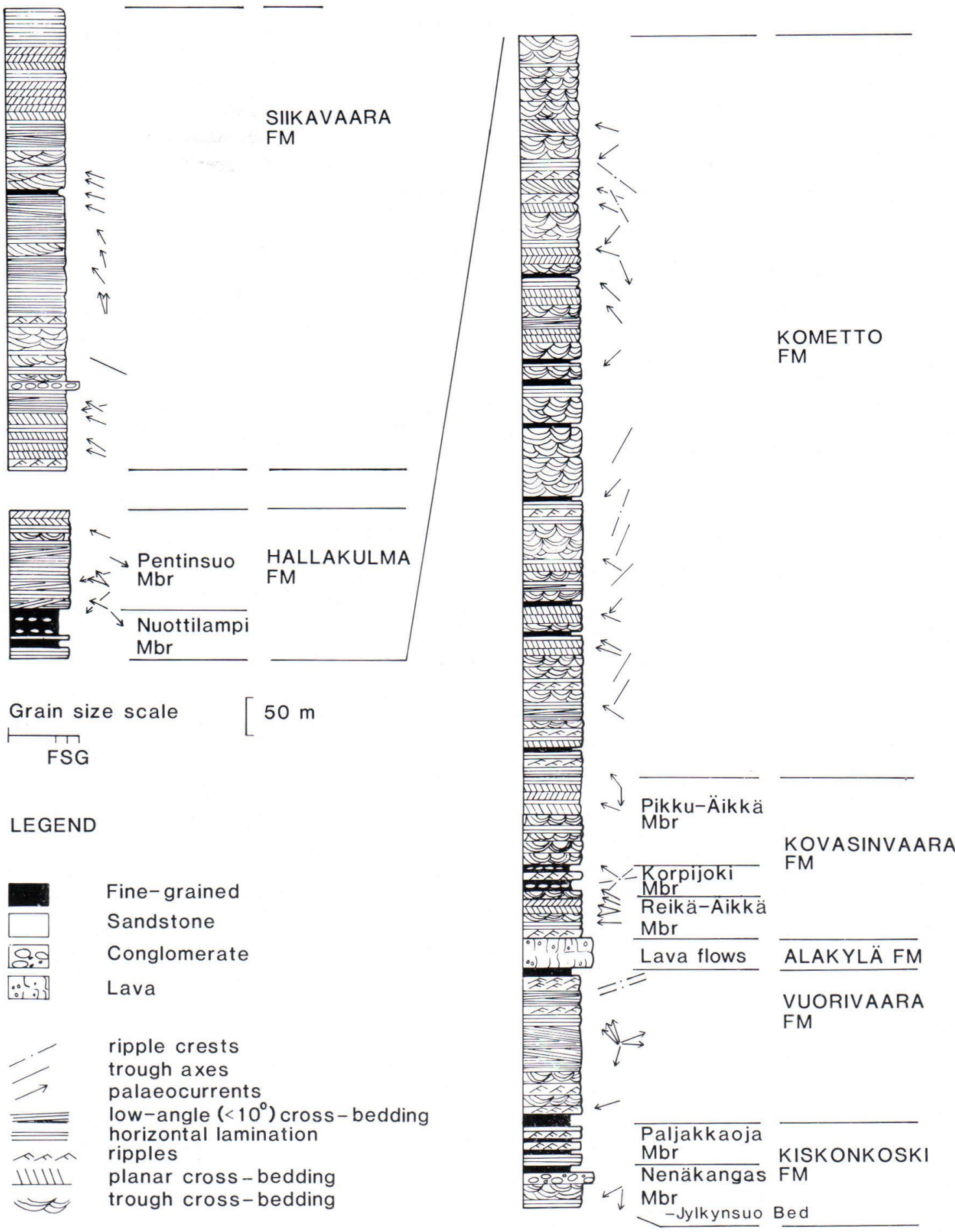

Fig. 11. Combined type sections with average thicknesses and relative positions for the formations of the East Puolanka Group. 
Formation of the Korvuanjoki Group; (2) the Vuorivaara Formation; (3) the volcanic Alakylä Formation; (4) the Kovasinvaara Formation; (5) the Kometto Formation; (6) the Hallakulma Formation; and (7) the Siikavaara Formation. These new or revised stratigraphic names are proposed after careful evaluation of the depositional concepts and existing nomenclature so that the earlier names by Laajoki (1980a), Strand (1985) and Härmä (1986) for these units should no longer be used.

Age: In South Puolanka and at Hukkavaara, northeast of Vuorivaara, the group is cut by diabase dikes whose zircon ages are $2050+-50 \mathrm{Ma}$ (Laajoki 1973) and >2200 Ma (O. Kouvo, written comm. 1983), respectively. For the overlaying Kaleva iron-formations at Pääkkö the whole rock $\mathrm{Pb}-\mathrm{Pb}$ age is $2080+-45 \mathrm{Ma}$ (Sakko \& Laajoki 1975).

\section{Kiskonkoski Formation (new name)}

Type area and section: The type section is located near the bend of the river Korvuajoki near to the rapids of Kiskonkoski. Some reference outcrops and local boulders of the conglomerates can be found to the east of the type section, especially in the Nenäkangas area. This formation is a counterpart of the basal part of Laajoki's (1980a) arkosite formation, but that formation is divided in this paper into the Kiskonkoski, Vuorivaara, Alakylä and Kovasinvaara Formations.

Contacts and thickness: The lower contact is not exposed but the Nenäkangas-type conglomerates evidently indicate a major unconformity with the Korvuanjoki Group (Laajoki 1988b). The formation is conformably overlain by the Vuorivaara Formation and its thickness is 50$150 \mathrm{~m}$.

Subdivision and lithology: The Kiskonkoski Formation consists of polymictic conglomerates, sandstones and fine-grained rocks subdivided into two members: (1) the Nenäkangas Member (new name) is characterized by the occurrence of polymictic crudely bedded conglomerates and coarse-grained feldspathic arenitic sandstones mostly with trough cross-bedding. The clasts of the conglomerates vary in composition from well rounded vein quartz and quartz arenites to rounded feldspathic arenites and gneissic tonalites-granodiorites. More detail descriptions are given by Strand (1985) and Laajoki (1988b). In Kiskonkoski the conglomerate bed, which is up to $6 \mathrm{~m}$ in thickness, is named the Jylkynsuo Bed (new name, Fig. 12). Some $8 \mathrm{~m}$ beneath this conglomerate a $0.5-1 \mathrm{~m}$ thick carbonate-rich bed occurs in sandstones. The conglomerate is overlain by 3-4 m of massive siltstones. (2) the Paljakkaoja Member (new name) contains massive, partly graded sandstones, fine-grained rippled sandstones and massive or laminated mudstones.

Depositional setting: The Kiskonkoski formation was deposited in the distal parts of an alluvial plain (Strand 1985, 1988). The sudden change from gravelly beds to the thick fine-grained deposits indicates that the rivers had deep channels and possibly a meandering character (cf. Allen 1965; Jackson 1978)

\section{Vuorivaara Formation (new name)}

Type area and section: The Vuorivaara Formation is named after Vuorivaara, a hill north of the village Suolijärvi. The type section is located on the western side of the hill. Some reference outcrops can be found to the northeast of Vuorivaara. Previously (e.g. Laajoki 1980a, Strand 1985) these rocks were included in Laajoki's (1973) arkosite formation.

Contacts and thickness: The lower contact with the Kiskonkoski Formation is gradational. The upper contact is not exposed but in the type section the uppermost parts become finer-grained and there seems to be a gradational change to the Kovasinvaara Formation. Locally the formation is overlain by the lavas of the Alakylä Forma- 
Fig. 12. Crudely bedded conglomerate (the Jylkynsuo Bed) of the Nenäkangas Member of the Kiskonkoski Formation. Clasts vary in composition from well rounded vein quartz and quartz arenites to rounded feldspathic arenites and gneissic tonalitesgranodiorites. Label $16.5 \mathrm{~cm}$. Photo K. Strand.

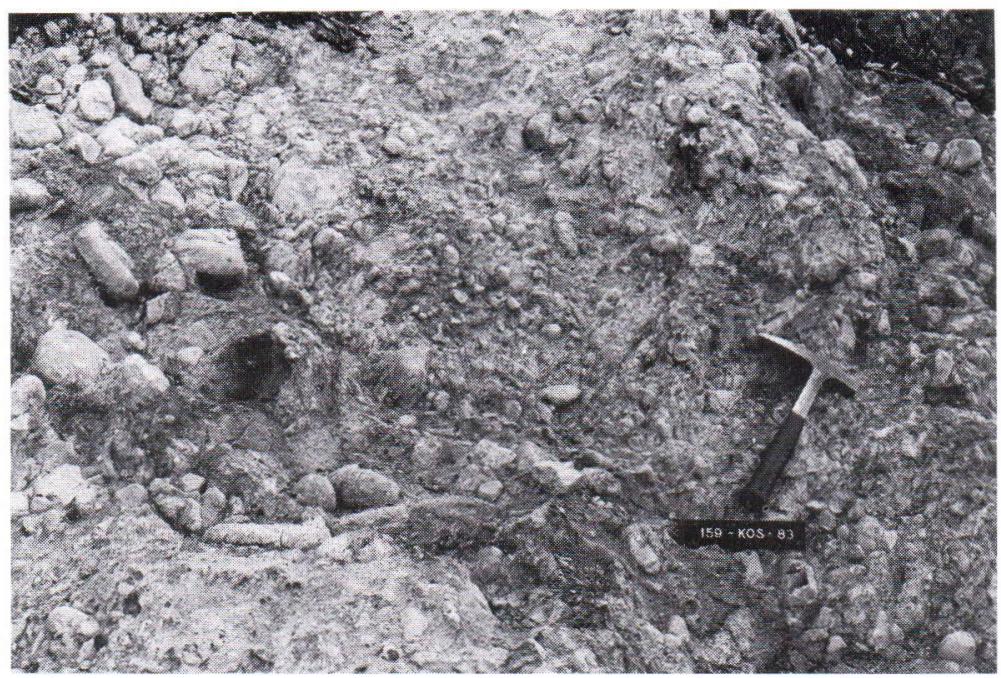

tion. The total thickness of the Vuorivaara Formation is estimated as being up to $250 \mathrm{~m}$.

Lithology: The main lithologies are low-angle cross-bedded or rippled, medium to coarsegrained sandstones forming a succession of some 100 to $150 \mathrm{~m}$ in thickness. Rippled sandstones are more abundant in the upper parts of the succession. The lowermost $20 \mathrm{~m}$ of the succession is characterized by several, $10-60 \mathrm{~cm}$ thick, sets of trough cross-bedded sandstones associated with rippled sandy interbeds. The palaeocurrents responsible for the low-angle cross-bedding show bipolar directions for the flow (Fig. 11). The sandstones are quartzose arenitic to feldspathic arenitic showing unimodal grain-size distributions. Polycrystalline quartz and lithic clasts are lacking. Fine-grained rocks are a minor part of the formation both beneath and above the sandy succession described.

Depositional setting: The low-angle cross-beds with bipolar foreset dips and successions of rippled and horizontally laminated sandstones suggest deposition at a clastic shoreline (cf. Elliott 1978; McCubbin 1982; Reinson 1984). It is interpreted by Laajoki et al. (1985) as representing the deposits of the foreshore and upper shoreface which, by succeeding regressional de- velopment, become part of a larger barrier beach complex.

\section{Alakylä Formation (new name)}

Type area: This metalava formation is named after a village along the southern side of the river Siikajoki in Puolanka. It is located in the central part of the study area and its type location occurs at the northeastern edge of the hill Kovasinvaara. The lavas east of Lukkarinvaara (Fig. 1), first described by Väyrynen (1928, p. 50), are considered as an allochthonous part of the Alakylä Formation.

Contacts and thickness: The lavas of the Alakylä Formation with associated diabases form an igneous body between the Vuorivaara and Kovasinvaara Formations. Its contacts are not exposed and its estimated thickness is some $20-50 \mathrm{~m}$.

Lithology: The formation consists of massive or amygdaloidal basaltic lavas composing only of few flows or, in some places, only a single farreaching flow. Thin bedded tuffites are locally associated with the lavas. The lavas show a greenschist facies parageneses and porphyritic textures. Quartz and carbonate fill the amygdales. The 
Table 3. Chemical analyses of some metalavas of the Alakylä Formation. $\mathrm{Fe}_{2} \mathrm{O}_{3}{ }^{*}=$ total iron as $\mathrm{Fe}_{2} \mathrm{O}_{3}$. Sample No. 1 analysed by XRF at X-Ray Assey Laboratories, Canada and for samples Nos. 2-3 analyst: S. Kaakinen by SRM-18-XRF unit at Department of Geology, University of Oulu.

\begin{tabular}{lccc}
\hline & 1 & 2 & 3 \\
\hline $\mathrm{SiO}_{2} \%$ & 48.5 & 47.2 & 50.1 \\
$\mathrm{TiO}_{2}$ & 1.53 & 1.24 & 1.23 \\
$\mathrm{Al}_{2} \mathrm{O}_{3}$ & 13.3 & 12.9 & 12.2 \\
$\mathrm{Fe}_{2} \mathrm{O}_{3}{ }^{*}$ & 15.4 & 14.5 & 15.7 \\
$\mathrm{MnO}$ & 0.14 & 0.19 & 0.16 \\
$\mathrm{MgO}$ & 9.35 & 8.1 & 8.7 \\
$\mathrm{Cr}_{2} \mathrm{O}_{3}$ & $n . d$. & 0.00 & 0.00 \\
$\mathrm{CaO}$ & 2.83 & 5.63 & 3.43 \\
$\mathrm{Na}_{2} \mathrm{O}$ & 1.66 & 1.7 & 1.0 \\
$\mathrm{~K}_{2} \mathrm{O}$ & 2.71 & 0.13 & 0.06 \\
$\mathrm{BaO}$ & $n . d$. & 0.00 & 0.00 \\
$\mathrm{P}_{2} \mathrm{O}_{5}$ & 0.14 & 0.12 & 0.12 \\
$\mathrm{Ignition}$ loss & 2.93 & 7.50 & 5.85 \\
$\mathrm{~T}_{\text {otal }}$ & 98.5 & 99.2 & 98.6 \\
\hline
\end{tabular}

1. $90 \mathrm{~B} / \mathrm{KL}-70$

2. $112 \mathrm{~A} / \mathrm{KOS}-84$

3. $90 \mathrm{D} / \mathrm{KL}-70$

$\mathrm{SiO}_{2}$ content of the lavas indicates a composition of basalt (Table 3). The marked range in alkalines is obviously due to post-depositional modification and metamorphism. The results plotted on an alkali-silica diagram (Fig. 6) demostrate a subalkaline nature for the lavas.

Eruptive setting: The lavas reached clastic shoreline environments as can be deduced from the associated clastic deposits but the vent areas were probably located in more proximal areas where alluvial environments dominated. The flows were subaerial and assumed to be of the valley-fill type of fluidal basalt with a relatively high effusive rate. The eruptions are interpreted as being associated with fissures caused by the reactivation of those vertical crustal fractures which were mainly formed during intracratonic rifting. This event can, therefore, be incorporated into the early developmental stages of a continental margin when it was still repeatedly rifted by phases of crustal extension (Laajoki 1986b; Strand 1988). The eruptions also seem to be associated with some explosive activity because interstratified sediments in the study area and to the south in the Naulaperä region consist of fragmental tuffaceous material. This could mean that some lavas may also represent terminal events of some explosive eruptions (cf. Cas \& Wright 1987).

\section{Kovasinvaara Formation (new name)}

Type area and section: The Kovasinvaara Formation is well exposed on the northeastern side of the hill Kovasinvaara where the type sections for the two lowermost members are located. The uppermost member is to be seen as a few outcrops on the southern edge of the hill and on the most easterly side of the Siikavaara hill. An allochtonous part of the formation occurs east of Lukkarinvaara (Fig. 1). This formation includes the uppermost parts of Laajoki's (1980a, p. 9) arkosite formation.

Contacts and thickness: The change from the Vuorivaara Formation to the Kovasinvaara Formation is gradual except where the zone is occupied by the Alakylä Formation. The upper contact is not exposed but the lithologies seem to grade relatively quickly into the coarse sandstones of the Kometto Formation. The thickness of the Kovasinvaara Formation is some $250 \mathrm{~m}$.

Subdivision and lithology: The sandstones in the lower part of the Kovasinvaara Formation are finer-grained than those of the Vuorivaara Formation. They are quartzose arenitic and the successions contain relatively thick mudstone interbeds which become thicker upwards. These then pass upwards into unimodal quartz arenitic sandstones.

The formation is subdivided into three members: The lowermost sandstones form (1) the Reikä-Äikkä Member (new name) showing fine to medium grained sand-sets of some $5-10 \mathrm{~cm}$ thick with trough cross-bedding succeeding by horizontal laminated or rippled sands. Some solitary or grouped planar-type cross-beds also occur and the few measured palaeocurrents show trends to the west and northwest. The thin interbeds of sandstones of approximately the same 


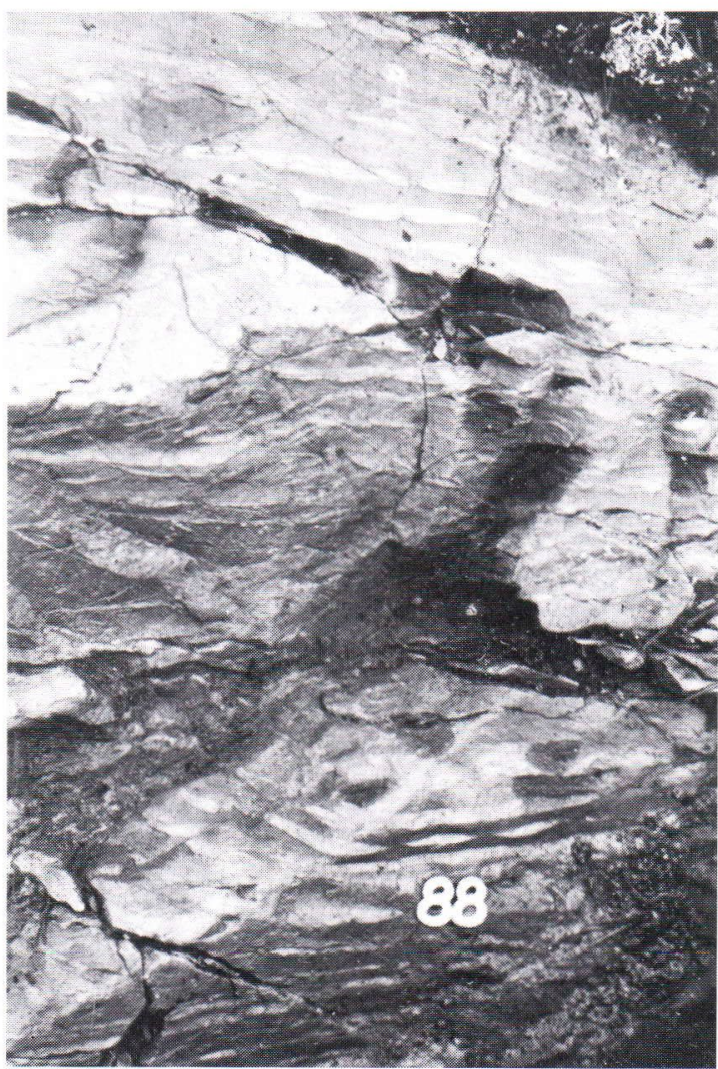

Fig. 13. Interbeds of fine sand, silt and mud showing wavy and lenticular bedding in the Korpijoki Member of the Kovasinvaara Formation. Label $1.2 \mathrm{~cm}$. Photo K. Strand.

type as outlined above and the fine-grained rocks arranged in $2-20 \mathrm{~m}$ thick units with sharp contacts form (2) the Korpijoki Member (new name). The fine-grained units are mostly laminated siltstones and mudstones but show abundant wavy to lenticular bedding with fine sandstones (Fig. 13). The member has a thicker intercalation relationship with the lower part of (3) the PikkuÄikkä Member (new name) which consists of medium to coarse-grained, mature, slightly bluish sandstones, in some places, asymmetrically rippled with straight ripple crests. In the upper part of the member the sandstones are low-angle cross-bedded and there are some planar crossbeds $(10-15 \mathrm{~cm})$ which show bipolar palaeocurrents. Interlayers of laminated sand are abun- dant, some of them contain small muddy intraclasts.

Depositional setting: The succeeding regressional development after Vuorivaara time allowed a formation of back barrier regions with lagoons and inlets in which the Kovasinvaara Formation was deposited (Laajoki et al. 1985; Härmä 1986). In that model the Korpijoki Member represents the deposits of a microtidal lagoon (cf. Tankard \& Hobday 1977; Reinson 1984). The ReikäÄikkä Member corresponds mostly to deposits of the barrier beach itself while some sedimentinflux may also have occured from the nearby alluvial plain (cf. Vos \& Eriksson 1977). The deposition of the Pikku-Äikkä Member seems to represent a short transgressive period during which quartz arenitic sands were deposited in tidal channels and deltas. The bipolar trends of the palaeocurrents support this interpretation (Härmä 1986).

\section{Kometto Formation (new name)}

Type area and section: The Kometto Formation is well exposed at the northeastern corner of Siikavaara, a north-south trending hill belt in Puolanka. Kometto is a rocky precipice on the northern end of Siikavaara and serves as an excellent type section (Fig. 14). This formation is a counterpart of the heterogenic quartzite member of Härmä's (1986) Siikavaara formation.

Contacts and thickness: There is a narrow gradation from the Kovasinvaara Formation to the Kometto Formation. The upper boundary with the Hallakulma Formation is gradational but the contact zone is often intruded by a diabase sill. The total thickness of the Kometto Formation in the type area is $1000-1100 \mathrm{~m}$.

Lithology: The formation contains predominantly quartz arenitic, medium to coarse-grained sandstones. Matrix-rich varieties exist mostly as $10-30 \mathrm{~cm}$ thick interbeds with trough crossbedding and they contain a lot of fine-grained intraclasts. These vanish in the overlying thick, 


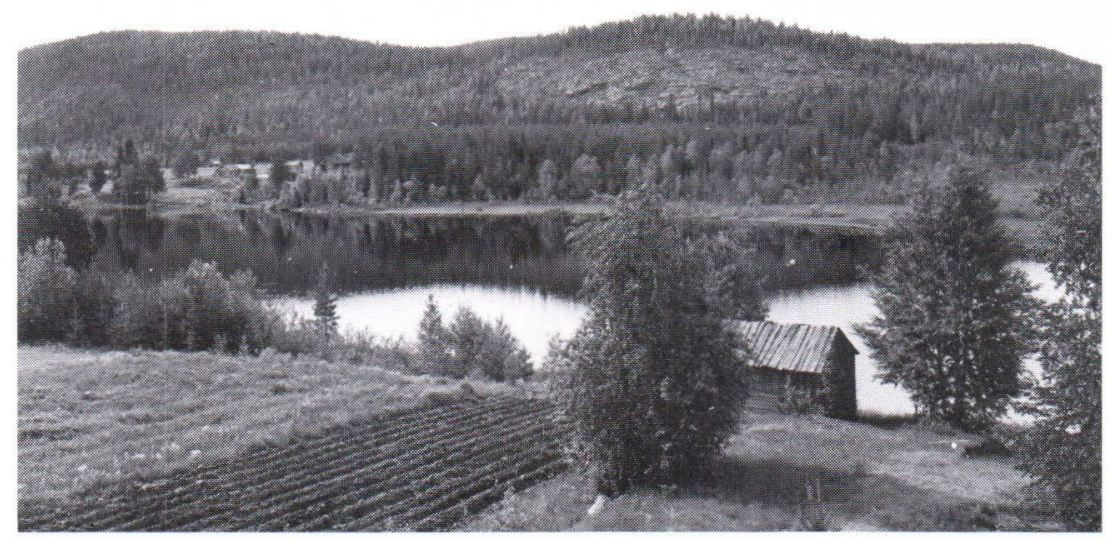

Fig. 14. North-easterly view of the exposed quartzites of the Kometto Formation from the lakeside of Iso Siikajärvi. Height of cliff about $60 \mathrm{~m}$. Photo K. Laajoki.

trough or planar cross-bedded sandstone successions. The matrix minerals of the sandstones are sericite, carbonate, some turmaline and rutile. The clasts are mostly well rounded monocrystalline quartz. Horizontal laminations with some rippled sets are abundant, especially in the lower levels of the formation. Siltstones and mudstones occur as interbeds some $10-20 \mathrm{~cm}$ in thickness.

Some cyclic sequences are associated within the $700-900 \mathrm{~m}$ interval in the middle of the formation. The cycles are upward fining and the sandy, predominantly trough cross-bedded, deposits turn upwards to laminated fines. Some wedgeshaped, mostly planar cross-bedded macroform cosets up to $3.5 \mathrm{~m}$ thick with rippled lower and upper sets are located in the upper part of the formation and can be traced laterally for one hundred meters. Palaeocurrents show trends to the west and southwest. The foreset dips of the planar cross-beds open mostly to the west and northwest but southern directions also occur.

The fine-grained, originally muddy intraclasts have largely recrystallized to turmaline. This is due to the large-scale redistribution of boron during diagenesis and the subsequent metamorphism of these sediment piles (Ojakangas 1965).

Depositional setting: The deposits of the Kometto Formation were formed by the prograding of an alluvial plain environment over the coastal and shallow-marine deposits (Härmä 1986). During periods of weak detrital influx the alluvial plain margin may have been affected by coastal reworking as indicated by plane-bedded units with rippled surfaces, especially in the lowest levels (cf. Vos \& Eriksson 1977). The thick cross-bedded successions represent distal braided river deposits with shallow channels and wide flood plains, whereas the wedge-shaped thick macroforms generally represent the lateral accretion deposits of the river accompanied by channel filling bedforms (Miall 1985).

\section{Hallakulma Formation (new name)}

Type area and section: The type area is located in the south-eastern parts of the Siikavaara hill 

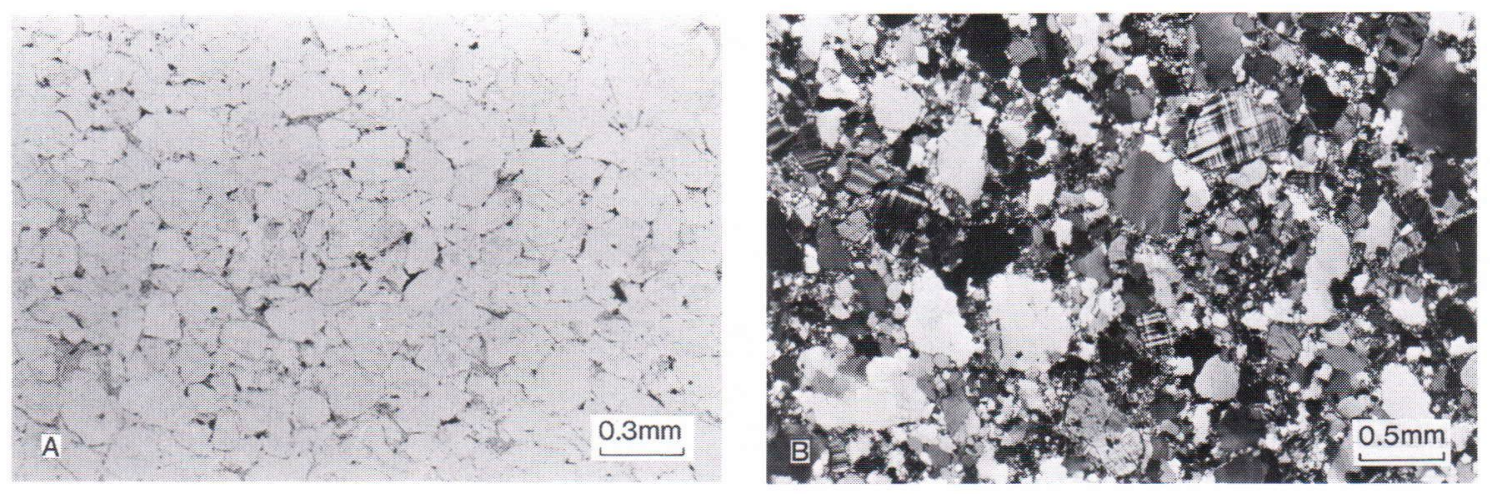

Fig. 15 A. Photomicrograph of sandstone of the Pentinsuo Member of the Hallakulma Formation showing the quartz arenitic composition and clear unimodal grain size distribution. PAH-84-59.6. B. Photomicrograph of sandstone of the Siikavaara Formation showing the quartzose-feldspathic arenitic composition, rounded clasts and moderate sorting. PAH-84-49.1. Cross-polarized light. Photos P. Härmä.

in the vicinity of Hallakulma. The formation appears to extend laterally to the north and it counterparts the phyllite and orthoquartzite members of Härmä's (1986) Siikavaara formation.

Contacts and thickness: The lower contact with the Kometto Formation is gradational. In the type area the Hallakulma Formation is laterally almost at the same stratigraphic level as the Kometto Formation. The upper contact with the Siikavaara Formation is not exposed. The thickness of the Hallakulma Formation is about $130-200 \mathrm{~m}$.

Subdivision and lithology: The formation is subdivided into two members: The fine-grained rocks form (1) the Nuottilampi Member (new name, displaces Härmä’s (1986) phyllite member) some $30-100 \mathrm{~m}$ in thickness. They consists of dark coloured, laminated, rippled or massive mudstones which are partly lenticular bedded with silt and sand-sized material. Each mudstonetype forms distinct units several meters in thickness. The fine-grained rocks are then sharply succeeded by the quartz arenitic (2) Pentinsuo Member (new name, displaces Härmä's (1986) orthoquartzite member) more than $110 \mathrm{~m}$ in thickness. The sandstones are well sorted, mature and unimodal with rounded to well-rounded quartz clasts (Fig. 15A). The colour of the rocks is slight- ly bluish and they are predominantly low-angle cross-bedded $\left(2^{\circ}-10^{\circ}\right)$ or horizontally laminated. Set thicknesses vary from 50 to $80 \mathrm{~cm}$. Palaeocurrents are bipolar to the northwestsoutheast for the low-angle crossbeds.

Depositional setting: The detrital influx of the braided streams to the flat alluvial plain diminished so much during this stage that shoreline processes came to dominate. The Nuottilampi Member represents tidal flat deposits, mostly suspension transported mudstones in a partial back-barrier region (cf. Reineck 1972; Weimer et al. 1982; Reinson 1984). The Pentinsuo Member with a sharp contact against the underlying Nuottilampi Member indicates that the continued transgressive development rapidly switched the sandy barriers within the foreshore and backshore environments above the tidal flats. The abundant occurrence of bipolar low-angle cross stratification in Pentinsuo Member indicates deposition in the swash zone of a foreshore.

Siikavaara Formation (Härmä 1986, p. 14, redefined in this study)

Type area and section: The name Siikavaara formation was first used by Härmä (1986) to include the whole quartzitic sequence in the Siikavaara- 
Kometto area but we redefine it to comprise only the topmost feldspar-bearing quarzites which Härmä (op. cit.) classified as the subarkose member of his Siikavaara formation. The Siikavaara Formation can be mapped from a few outcrops at the top of the northern part of Siikavaara. The type section is located southwest of the Kometto area.

Contacts and thickness: The lower boundary of the formation is not exposed but the sandstone composition differs so much from that of the Hallakulma Formation that this boundary probably represents an erosional surface. The upper contact is the present erosional surface. The preserved thickness of the formation is up to $600 \mathrm{~m}$.

Lithology: The material of the formation is coarse to very coarse, moderately sorted sand with rounded to very rounded clasts and its composition is feldspathic to quartzose arenitic (Fig. 15B). The clasts vary from polycrystalline and monocrystalline quartz to potassium feldspar and some albite. In the lower levels some granulesized gravelly layers $15-20 \mathrm{~cm}$ thick occur with a few fine-grained intraclasts. The sandstones are predominantly large-scale low-angle cross-bedded or horizontally laminated but in lower levels of the formation some trough sets also occur. The sequences are generally non-cyclic in lithofacies transitions. The trough axes trend between west and north. Foreset dips for the low-angle crossbedded sets open mostly to the west and northwest.

Depositional setting: The Siikavaara Formation was deposited predominantly in a clastic shoreline which is suggested by the abundant occurrence of low-angle cross-stratification with internal lamination subparallel to the bases of largescale wedge-shaped sets. Stratification and set boundaries were formed parallel to the changing slope of the beachface and dip generally seawards (cf. McCubbin 1982). Source-area changes have resulted in immature detrital material and, most probably, the lowermost parts of the formation also contain some remnants of the alluvial plain deposits, as indicated by gravelly and trough cross-bedded units. These may have been slightly effected by costal reworking before the final prograding of shoreline environments and the deposition of relatively thick successions of plane-bedded and low-angle cross-bedded sands.

\section{Conclusions and regional correlations}

Since the end of the last century, the stratigraphy of the Karelian formations has been one of the principal targets of study in the geology of Finland. Unfortunately, however, there has been no Finnish recommendation or procedure for establishing formal stratigraphic units. This, together with the partial understanding of depositional environments and facies relationships and the way of including scattered occurrences into one or two large specific groups without any real or proved physical connections have lead to interminable arguments about stratigraphic nomenclature and correlations. One way out of this tangle is to apply international recommendations and take into account genetic criteria. Regional correlations demand that basin analysis and tectonics, as well as age considerations, should also be considered a subject of stratigraphy (see Miall 1984). This is why Laajoki (1988a, 1988b, 1988c) has recently introduced also the tectofacies concept to the study of the Karelian formations of Finland.

In the following we make some lithostratigraphical correlations, mostly at the group level, within the Kainuu Schist Belt and with the adjacent areas (Table 4) and also draw some wider conclusions on the tectonic setting. With respect to other, slightly different, interpretations the reader is referred to Gaál (1986), Kontinen (1986, 1987) and Gaál \& Gorbatschev (1987) who consider most of the Karelian formations to be anorogenic craton-cover sediments.

The Kurkikylä Group forms a relic of a continental rift sequence whose western extension is 
Table 4. Correlations, at the provincial scale, with the traditional informal division of the Karelian formations of the areas adjacent to that studied (see text for more detailed regional correlations).

\begin{tabular}{|c|c|c|c|}
\hline Study area & North Karelia (1) & Kuusamo (2) & Soviet Karelia (3) \\
\hline $\begin{array}{c}\text { East Puolanka } \\
\text { Group }\end{array}$ & \multirow{2}{*}{$\begin{array}{l}\text { Jatuli } \\
\text { Group }\end{array}$} & $\begin{array}{c}\text { Middle \& Upper } \\
\text { Jatuli Groups }\end{array}$ & $\begin{array}{l}\text { Middle \& Upper } \\
\text { Jatulian }\end{array}$ \\
\hline $\begin{array}{c}\text { Korvuanjoki } \\
\text { Group }\end{array}$ & & $\begin{array}{l}\text { Lower Jatuli } \\
\text { Group }\end{array}$ & $\begin{array}{c}\text { Lower } \\
\text { Jatulian }\end{array}$ \\
\hline $\begin{array}{l}\text { Kurkikylä } \\
\text { Group }\end{array}$ & $\begin{array}{l}\text { Sariola } \\
\text { Group }\end{array}$ & $\begin{array}{c}\text { Lower Lapponia } \\
\text { Group }\end{array}$ & $\begin{array}{l}\text { Sumian- } \\
\text { Sariolian }\end{array}$ \\
\hline
\end{tabular}

(1) Marmo \& Ojakangas 1984; Marmo et al. 1988

(2) Silvennoinen 1980, 1985

(3) Kratz \& Mitrofanov 1980; Sokolov \& Heiskanen 1985

found in the Jaurakka area (Meriläinen 1977, 1980). Evidently it formed a depositional system of its own and so it cannot be correlated lithostratigraphically with any other group in Kainuu. Chronostratigraphically and in the tectonic sense it is, however, readily correlated with other SumiSariola type occurrences in northern Finland; e.g. with the Saari-Kiekki group' (Luukkonen \& Lukkarinen 1986) and the Honkala members of the arkosite formation in South Puolanka (Laajoki 1973).

In North Karelia similar rock types are considered to belong to the Sariola Group (Marmo et al. 1988). Although glaciogenic deposits similar to those of the Urkkavaara Formation (Marmo \& Ojakangas 1983, 1984; Marmo et al. 1988) have not been found in the study area; subaqueously redeposited gravels, disturbed sandy lenses and some oversized clasts in the fine-grained rocks in the upper part of the Laanhongikko Formation suggest deposition under glacial or periglacial conditions (Strand 1988). Furthermore, our recent observations indicate that there are glaciogenic deposits at Väyrylänkylä in South Puolanka in approximately this same stratigraphic position. Recently Ojakangas $(1985,1988)$ has summarized the records of an early Proterozoic

\footnotetext{
1 Luukkonen and Lukkarinen (1986) include these rocks into the Sariola Group, but we prefer to consider them as a group of their own.
}

glaciation between different cratons and opened a discussion as to their significance in intracontinental and intercontinental correlations.

The nomenclature in the Kuusamo area differs in some instances from that of the adjacent areas (see Table 4) and the Kurkikylä-type rocks are referred to the Lower Lapponia Group (Silvennoinen 1980, 1985). The Kurkikylä Group is considered by Laajoki (1988b, 1988c, in press) as a type example of the Sumi-Sariola tectofacies and for wider correlations the reader is referred to his papers.

The peneplanation stage, which was characterized by intensive chemical weathering and from which is preserved the palaeosol to separate the Kurkikylä Group from the Korvuanjoki Group, is of general and extensive development thus providing a good boundary for correlation. The significance of this kind of sedimentary event in correlation has recently been emphasized by Marmo et al. (1988) and Ojakangas (1988). Our studies in the Jaurakka area indicate that the quartz-pebble conglomerates and associated quartzites of the Turpeisenvaara area can readily be included into the Korvuanjoki Group. Both our own results and those of others (Kontinen 1986, Gehör \& Havola 1988) show, however, that rock types similar to those of as in our Korvuanjoki Group are rare in other parts of the Kainuu Schist Belt. 
In North Karelia the palaeosol mentioned above is reported as the Hokkalampi Formation (Marmo et al. 1988). The overlaying quartz pebble conglomerates and quartzites of the Vesivaara and Koli Formations of the Jatuli Group (Marmo et al. 1988) represent a similar alluvial depositional stage as the Paljakkavaara Formation does in Kainuu. In Soviet Karelia the Lower Jatulian aluminous and mature successions (Sokolov \& Heiskanen 1985) are similar to those of the Korvuanjoki Group (see Table 4). The Korvuanjoki Group forms one of the type examples of Laajoki's (1988b, 1988c, in press) Kainuu-Lapponi tectofacies and a more detailed discussion of its distribution is given in these papers.

Our conclusion is that the formation of the Korvuanjoki Group was connected with the early phases of crustal extension and stretching before complete crustal breakup and the deposition took place in half-grabens still in a cratonal setting. The group is seen to correspond to the incipient ocean/inland basin stage in the development of a continental margin.

The East Puolanka Group forms part of a thick, wide, mostly quartzitic cover which was deposited either directly on the late Archaean Kuhmo Complex or on the Korvuanjoki Group. Kontinen (1986) has mapped these type of rocks as the Hyrynsalmi Group and Gehör \& Havola (1988) as the Vuokatti Group furthermore the bulk of the Karelian sequence in Kuusamo (Silvennoinen 1972) belongs to this cover. In addition some similarities can also be seen with sequences of the Peräpohja area (Perttunen 1985).

The closest correlation to some extent can be made with the Hyrynsalmi area (Kontinen 1986) where the Syväjoki Formation seems to represent similar alluvial plain deposits to our Kiskonkoski Formation, although the fluvial-systems themselves must be different because the fluvial deposits do not usually represent laterally continuous units of wide extent. In North Karelia, the Jero Formation (Marmo et al. 1988) which is a counterpart of the arkose quartzite formation of
Piirainen (1968) and Piirainen et al. (1974), seems to have been deposited approximately at the same time. The shoreline-shallow marine stages represented by the Hietavaara, Lauttavaara and Tuomela Formations at Hyrynsalmi (Kontinen 1986) may be contemporary with our coastalshallow marine Vuorivaara and Kovasinvaara Formations. The Katajavaara Formation at Hyrynsalmi and the Alakylä Formation are not necessarily coeval but they seem to represent those sporadic phases of volcanism which occurred during the rifting of an early stage continental margin. A prograding alluvial environment is recorded in the study area by the Kometto Formation but it seems to represent a fluvialsystem of its own and our present observations indicate that it was not deposited in the southern areas of Kainuu and so it is not necessarily coeval with any other formations. The later clastic shoreline-shallow marine stages represented in the study area by the Hallakulma and Siikavaara Formations may be of more general and extensive development. It is possible that the Iso Tuomivaara Formation at Hyrynsalmi (Kontinen 1986) and the Siikavaara Formation are contemporaneous as both contain relatively immature clastic material and record a transition from fluvial to shallow marine environments although the Iso Tuomivaara Formation exhibits greater proximity and propably represents a different fluvialsystem.

The successions of the western side of the northern part of the Kainuu Schist Belt preceeding the deposition of the Väyrylä Group represent the effect of block faulting which does not exist in the eastern side. The source-areas for the sedimentary material were in the west (Kangas 1985 ) and so there is no particular need to correlate the Vihajärvi and Somerjärvi Groups (Fig. 2) with the successions encountered in the eastern side.

As a whole, the East Puolanka Group represents low relief platformal conditions and exhibits records of three general transgression phases cratonwards over the attenuated crust. 
Evidence from other parts of the Kainuu Schist Belt indicates that the group is overlain by black mudstones and dolomites representing outershelf sedimentation. Subsequent drowning of the platformal shelf is then indicated by Kaleva-type successions of turbidites, black mudstones and iron-formations which overly these unconformably and were possible formed by activation of existing listric faults during phases of crustal extension. The East Puolanka Group represents the lower part of a large opening clastic wedge on a divergent continental margin deposited over a period of two hundred million years or so. The East Puolanka Group is a typical example of Laajoki's (1988b, 1988c, in press) Jatuli tectofacies.

To summarize, the early Proterozoic supracrustal rock record of the study area which is classified into the Kurkikylä, Korvuanjoki and East Puolanka Groups demostrates a progressive development from rift stages to the low relief platformal shelf of a continental margin.

\section{References}

Allen, J.R.L., 1965. A review of the origin and characteristics of recent alluvial sediments. Sedimentology 5, 91-191.

Basu, A., 1981. Weathering before the advent of land plants: Evidence from unaltered detrital K-feldspars in CambrianOrdovician arenites. Geology 9, 132-133.

Cas, R.A.F. \& Wright, J.W., 1987. Volcanic successions: modern and ancient: a geological approach to processes, products and successions. Allen \& Unwin, London, 528 p.

Elliott, T., 1978. Clastic Shorelines. In H.G. Reading (ed.) Sedimentary environments and facies. Blackwell Sci. Publ. Oxford, pp. 143-177.

Enkovaara, A.; Härme, M. \& Väyrynen, H., 1953. Kivilajikartan selitys - Explanation to the map of rocks. Lehdet - Sheets C5 \& B2, Oulu-Tornio. Suomen geologinen yleiskartta - The general geological map of Finland, 1:400 000. English summary. 153 p. ( Map published 1952).

Eriksson, K.A., 1978. Alluvial and destructive beach facies from the Archaean Moodies Group, Barberton Mountainland, South Africa and Swaziland. In A.D. Miall (ed.) Fluvial Sedimentology. Can. Soc. Petrol. Geol. Mem. 5, $287-311$.
Acknowledgements. The present paper is based on the studies of K. Laajoki and K. Strand conducted in 1982 - 1983 as part of the research project 04/054 of the Academy of Finland, and on studies the authors carried out in 1984 in the research project of Oulu University supported by the Geological Survey of Finland and the municipalities of Puolanka and Suomussalmi. The work was continued in 1987-1988 by K.Strand as part of his Ph.D. research project at the University of Oulu first supported by a one-year research grant from the Emil Aaltonen Foundation and then financed by the Academy of Finland. The Kainuu Cultural Foundation is thanked for fieldwork support to K. Strand in 1988. The Exploration Department of the Geological Survey of Finland is acknowledged for results of the field work collected in 1970-1975 and P. Ervamaa and T. Heino are thanked for their co-operation in the research project conducted in 1984. Our warmest thanks to all those who have assisted us during the projects. Thanks are also due to S. Kaakinen for the chemical analyses. Sheila Hicks corrected the English of the manuscript and Kristiina Karjalainen drafted the maps and sections. We thank A. Kontinen for helpful comments and improvements.

Document storage and sample material. All the documents, maps and sample material related to this study are stored at the Department of Geology, University of Oulu.

Gaál, G., 1986. Svekokarjalainen tai svekofenninen orogenia - olisiko nimenvaihdos tarpeen? Geologi 38, $123-125$.

— \& Gorbatschev, R., 1987. An outline of the Precambrian evolution of the Baltic Shield. In G. Gaal \& R. Gorbatschev (eds.) Precambrian geology and evolution of the Central Baltic Shield. Precambr. Res. 35, 15-52.

Galloway, W.E., 1989. Genetic Stratigraphic Sequences in Basin Analysis I: Architecture and Genesis of FloodingSurface Bounded Depositional Units. Am. Ass. Petrol. Geol. Bull. 73, 143-154.

Gehör, S. \& Havola, M., 1988. The depositional environment of the early Proterozoic Tuomivaara iron-formation and associated metasediments, eastern Finland. In K. Laajoki \& J. Paakkola (eds.) Sedimentology of the Precambrian formations in eastern and northern Finland. Geol. Surv. Finland, Spec. Paper 5, 109-133.

Härmä, P., 1986. Pohjois-Puolangan Siikavaaran-Lukkarinvaaran alueen alaproterotsooisten metasedimenttien litostratigrafia, paleosedimentologia ja rakenne. [The lithostratigraphy, palaeosedimentology and structure of the Lower Proterotzoic metasediments of the SiikavaaraLukkarinvaara area in North Puolanka.] Res Terrae, Ser. B. $10,87 \mathrm{p}$.

Hedberg, H.D., 1976 (ed.) International Stratigraphic Guide. 
A Guide to Stratigraphic Classification, Terminology, and Procedure. John Wiley and Sons, New York, 200 p.

Irvine, T.N. \& Baragar, W.R.A., 1971. A guide to the Chemical Classification of the Common Volcanic Rocks. Can. J. Earth Sci. 8, 523-549.

Jackson, R.G., 1978. Preliminary evaluation of lithofacies models for meandering alluvial streams. In A.D. Miall (ed.) Fluvial Sedimentology. Can. Soc. Petrol. Geol. Mem. 5, 543-576.

James, W.G.; Mark, G.H. \& Suttner, L.J., 1981. Relative alteration of microcline and sodic plagioclase in semiarid and humid climates. J. Sed. Petr. 51, 151-164.

Kangas, R., 1985. Alaproterotsooisen Itä-Puolangan ryhmän länsiosan litostratigrafia, paleosedimentaatio ja rakenne, Puolanka. [The lithostratigraphy, palaeosedimentation and structure of the western parts of the Lower Proterozoic East Puolanka Group in Puolanka area, eastern Finland.] Res Terrae, Ser. B. 8, 111 p.

Kontinen, A., 1986. Early Proterozoic stratigraphy and sedimentation in the Hyrynsalmi area, Eastern Finland. In V.A. Sokolov \& K.I. Heiskanen (eds.) Early Proterozoic of the Baltic Shield. Proceedings of the FinnishSoviet Symposium held in Petrozavodsk 19th-27th August, 1985. Committee for Scientific and Tecnical co-operation between Finland and Soviet Union, Petrozavodsk, 75-103.

-, 1987. An early Proterozoic ophiolite - the Jormua maficultramafic complex, northeastern Finland. In G. Gaal \& R. Gorbatcshev (eds.) Precambrian geology and evolution of the Central Baltic Shield. Precambr. Res. 35, $313-341$.

Kratz, K. \& Mitrofanov, F., 1980. Main type reference sequences of the Early Precambrian in the U.S.S.R.. EarthSci. Rev. 16, 295-301.

Laajoki, K., 1973. On the geology of the South Puolanka area, Finland. Geol. Surv. Finland, Bull. 263, 54 p.

—, 1980a. Karjalaisten muodostumien alaosat Puolangan tutkimusten valossa. [The lowermost Karelian formations on the basis of the studies at Puolanka.] Res Terrae, Ser. B. $1,18 \mathrm{p}$.

-, 1980b. Outlines of the Precambrian geology of the North Puolanka area, Finland. Res Terrae, Ser. A. 1, 11 p.

—, 1986a. The Central Puolanka Group - a Precambrian regressive metasedimentary sequence in northern Finland. Bull. Geol. Soc. Finland 58, 179-193.

- , 1986b. The Precambrian supracrustal rocks of Finland and their tectono-exogenic evolution. Precambr. Res. 33, $67-85$.

—, 1988a. The Pyssykulju Formation - a late Kalevian (early Proterozoic) orthoquartzite phase in Kainuu, northern Finland. In K. Laajoki \& J. Paakkola (eds.) Sedimentology of the Precambrian formations in eastern and northern Finland. Geol. Surv. Finland, Spec. Paper 5, $135-148$.
-, 1988b. Nenäkangas-type conglomerates — an evidence of a major break in the sedimentation of the early Proterozoic (»Jatulian») quartzites in Kainuu. In K. Laajoki \& J. Paakola (eds.) Sedimentology of the Precambrian formations in eastern and northern Finland. Geol. Surv. Finland, Spec. Paper 5, 91-107.

-, 1988c. Karjalaisten muodostumien jako tektofasieksiin. With an English summary: Grouping of the Karelian formations into tectofacies. In V. Lappalainen \& H. Papunen (eds.) Tutkimuksia geologian alalta (Studies in the Field of Geology). Annales Universitatis Turkuensis. Ser. C, Tom 68, 21-30.

- , in press. Early Proterozoic tectofacies in eastern and northern Finland. In »Precambrian Continental crust and Its Economic Resources». Developments in Precambrian Geology. Elsevier Science Publisher.

— \& Korkiakoski, E., 1988. The Precambrian turbiditetempestite transition as displayed by the amphibolite-facies Puolankajärvi Formation, Finland. In M.J. Jackson (ed.) Aspects of Proterozoic Sedimentary Geology. Sediment. Geol. 58, 195-216.

— \& Luukas, J., 1988. Early Proterozoic stratigraphy of the Salahmi-Pyhäntä area, central Finland, with an emphasis on applying the principles of lithodemic stratigraphy to a complexly deformed and metamorphosed bedrock. Bull. Geol. Soc. Finland 60, 79-106.

-; Ervamaa, P.; Havola, M.; Heino, T.; Kangas, R. \& Strand, K., 1983. The Proterozoic Kainuu Schist Belt. In K. Laajoki \& J. Paakkola (eds.) Exogenic processes and related metallogeny in the Svecokarelian geosynclinal complex. Geol. Surv. Finland, Guide 11, 34-85.

—; Strand, K. \& Härmä, P., 1985. Oulun yliopiston geologian laitoksen ajalla 1.6.-31.12.1984 suorittamat Kainuun liuskejakson pohjoisosan kvartsiittien ja konglomeraattien kultakriittisyyttä koskeneet tutkimukset. Kainuun liuskejakson pohjoisosan tutkimusprojekti. Unpubl. Rept., Univ. Oulu, 55 p.

Larsen, V. \& Steel, R.J., 1978. The sedimentary history of a debris flow dominated Devonian alluvial fan — a study of textural inversion. Sedimentology 25, 37-59.

Luukkonen, E. \& Lukkarinen, H., 1986. Explanation to the stratigraphic map of Middle Finland. Geol. Surv. Finland, Rep. Inv. 74, 47 p.

Mack, G.H. \& Suttner, L.J., 1977. Paleoclimatic interpretation from a petrographic comparison of Holocene sands and the Fountain Formation (Pennsylvanian) in the Colorado Front Range. J. Sed. Petr. 47, 89-100.

Marmo, J.S. \& Ojakangas, R.W., 1983. Varhaisproterotsooinen Urkkavaara-muodostuma Kontiolahdella glasigeeninen metasedimenttisarja sariolaryhmän yläosassa. Summary: Early Proterozoic Urkkavaara Formation in Kontiolahti, North Karelia - a glacigenic metasedimentary sequence in the Upper Sariolan Group. Geologi 35, $3-6$. 
-; Ojakangas, R.W., 1984. Lower Proterozoic glaciogenic deposits, Eastern Finland. Geol. Soc. Am. Bull. 95, 1055-1062.

—; Kohonen, J.; Sarapää, O. \& Äikäs, O., 1988. Sedimentology and stratigraphy of the lower Proterozoic Sariola and Jatuli Groups in the Koli-Kaltimo Area, eastern Finland. In K. Laajoki \& J. Paakkola (eds.) Sedimentology of the Precambrian formations in eastern and northern Finland. Geol. Surv. Finland, Spec. Paper 5, 11-28.

Matisto, A., 1958. Kivilajikartan selitys - Explanation to the map of rocks. Lehti - Sheet D5, Suomussalmi. Suomen geologinen yleiskartta - The general geological map of Finland, 1:400 000. English summary. 115 p. (Map published 1954).

McCubbin, D.G., 1982. Barrier-Island and Strand-Plain Facies. In P.A. Scholle \& D. Spearing (eds.) Sandstone Depositional Environments. Am. Ass. Petrol. Geol. Mem. $31,247-279$.

Meriläinen, K., 1977. Suomen geologinen kartta - Geological map of Finland, 1:100 000. Lehti - Sheet 3531, Jonku. Geol. Surv. Finland.

- 1980. Stratigraphy of the Precambrian in Finland. Geol. Fören. Stockholm Förhand. 102, 177-180.

Miall, A.D., 1977. A review of the braided river depositional environment. Earth-Sci. Rev. 13, 1-62.

-, 1984. Principles of Sedimentary Basin Analysis. SpringerVerlag, New York, 490 p.

-, 1985. Architectural-element analysis: a new method of facies analysis applied to fluvial deposits. Earth-Sci. Rev. 22, 261-308.

North American Comission on Stratigraphic Nomenclature, 1983. North American Stratigraphic Code. Am. Ass. Petrol. Geol. Bull. 67, 841-875.

Ojakangas, R.W., 1965. Petrography and sedimentation of the Precambrian Jatulian quartzites of Finland. Bull. Comm. géol. Finlande 299, 74 p.

—, 1985. Evidence for Early Proterozoic glaciation: the dropstone unit - diamictite association. In $\mathrm{K}$. Laajoki \& J. Paakkola (eds.) Proterozoic exogenic processes and related metallogeny. Geol. Surv. Finland, Bull. 331, $51-72$.

-, 1988. Glaciation: An Uncommon »Mega-Event» as a Key to Intracontinental and Intercontinental Correlation of Early Proterozoic Basin Fill, North American and Baltic Cratons. In K.L. Kleinspehn \& C. Paola (eds.) New Perspectives in Basin Analysis. Springer-Verlag. New York, pp. $431-444$.

Okada, H., 1971. Classification of sandstone: analysis and proposal. J. Geol. 79, 509-525.

Perttunen, V., 1985. On the Proterozoic stratigraphy and exogenic evolution of the Peräpohja area, Finland. In K. Laajoki \& J. Paakkola (eds.) Proterozoic exogenic processes and related metallogeny. Geol. Surv. Finland, Bull. 331, 131-141.
Piirainen, T., 1968. Die Petrologie und die Uranlagerstätten des Koli-Kaltimogebiets im finnischen Nordkarelien. Bull. Comm. géol. Finlande 237, 99 p.

-, Honkamo, M. \& Rossi, S., 1974. A preliminary report on the geology of the Koli area. Bull. Geol. Soc. Finland 46, $161-166$.

Potter, P.E. \& Pettijohn, F.J., 1977. Paleocurrents and Basin Analysis, Second, Corrected and Updated Edition. Springer-Verlag, Berlin, 427 p.

Reineck, H.-E., 1972. Tidal Flats. In J.K. Rigby and W.K. Hamblin (eds.) Recognition of Ancient Sedimentary Environments. Soc. Econ. Paleontol. Mineral. Spec. Publ. $16,146-159$.

Reinson, G.E., 1984. Barrier-Island and Associated StrandPlain Systems. In R.G. Walker (ed.) Facies Models, Second Edition. Geosci. Canada Reprint Series 1, 119-140.

Sakko, M. \& Laajoki, K., 1975. Whole rock $\mathrm{Pb}-\mathrm{Pb}$ isochron age for the Pääkkö iron formation in Väyrylänkylä, South Puolanka area, Finland. Geol. Surv. Finland, Bull. 47, 113-116.

Schau, M. \& Henderson, J.B., 1983. Archean chemical weathering at three localities on the Canadian Shield. Precambrian Res. 20, 189-224.

Siedlecka, A.; Iversen, E.; Krill, A.G.; Lieungh, B.; Often, M.; Sandstad, J.S. \& Solli, A., 1985. Litostratigraphy and correlation of Archaean and Early Proterozoic Rocks of Finnmarksvidda and the Sodvaranger district. Norges geol. undersøkelse, Bull. 403: 7-36.

Silvennoinen, A., 1972. On the stratigraphic and structural geology of the Rukatunturi area, northeastern Finland. Geol. Surv. Finland, Bull. 257, 48 p.

-, 1980. (ed.) Jatulian geology in the eastern part of the Baltic Shield. Proceedings of a Finnish-Soviet Symposium held in Finland 21st-26th August, 1979. Committee for Scientific and Tecnical co-operation between Finland and the Soviet Union, Rovaniemi. 251 p.

-, 1985. On the Proterozoic stratigraphy of Northern Finland. In K. Laajoki \& J. Paakkola (eds.) Proterozoic exogenic processes and related metallogeny. Geol. Surv. Finland, Bull. 331, 107-116.

Simonen, A., 1980. The Precambrian in Finland. Geol. Surv. Finland, Bull. 304. 58 p.

Smith, N.D., 1974. Sedimentology and bar formation in the upper Kicking Horse River, a brided outwash stream. J. Geol. 82, 205-223.

Sokolov, V.A. \& Heiskanen, K.I., 1985. Evolution of Precambrian volcanogenic-sedimentary lithogenesis in the south-eastern part of the Baltic Shield. In K. Laajoki \& J. Paakkola (eds.) Proterozoic exogenic processes and related metallogeny. Geol. Surv. Finland, Bull. 331, $91-106$.

Strand, K., 1985. Alaproterotsooisen Kurkikylän ryhmän ja sen päällä olevien karjalaisten muodostumien litostratigrafia, paleosedimentologia ja rakenne. [The lithostratigra- 
phy, palaeosedimentology and structure of the Lower Proterozoic Kurkikylä Group and overlying Karelian formations.] Res Terrae, Ser. B. 7, 140 p.

- , 1988. Alluvial sedimentation and tectonic setting of the Lower Proterotzoic Kurkikylä and Kainuu Groups in northern Finland. In K. Laajoki \& J. Paakkola (eds.) Sedimentology of the Precambrian formations in eastern and northern Finland. Geol. Surv. Finland, Spec. Paper $5,75-90$.

Tankard, A.J.\& Hobday, D.K., 1977. Tide-dominated backbarrier sedimentation, early Ordovician Cape Basin, Cape Peninsula, South Africa. In D.K. Hobday \& K.A. Eriksson (eds.) Tidal Sedimentation. Sediment. Geol. 18, $135-159$.

Van Eysinga, F.W.B., 1970. Stratigraphic terminology and nomenclature; a guide for editors and authors. Earth-Sci. Rev. 6, 267-288.

Väyrynen, H., 1928. Geologische und petrografische Untersuchungen im Kainuugebiete. Bull. Comm. géol. Finlande 78. $127 \mathrm{p}$.
—, 1933. Über die Stratigraphie der Karelischen Formationen. Bull. Comm. géol. Finlande 101, 54-78.

-, 1954. Suomen kallioperä, sen synty ja geologinen kehitys. Otava, Helsinki, 260 p.

Vos, R.G. \& Eriksson, K.A., 1977. An embaymant model for tidal and wave swash deposits occurring within a fluvially dominated middle Proterozoic sequence in South Africa. In D.K. Hobday \& K.A. Eriksson (eds.) Tidal Sedimentation. Sediment. Geol. 18, 161-173.

Walker, G.P.L., 1970. Compound and simple lava flows and flood basalts. Bull. Volcanol. 35, 579-590.

Walker, T.R., 1984. 1984 SEPM presidential address: Diagenetic albitization of potassium feldspar in arkosic sandstones. J. Sed. Petr. 54, 3-16.

Weimer, R.J.; Howard, J.D. \& Lindsay, D.R., 1982. Tidal Flats and Associated Tidal Channels. In P.A. Scholle \& D. Spearing (eds.) Sandstone Depositional Environments. Am. Ass. Petrol. Geol. Mem. 31, 191-245.

Received September 16, 1988

Revision accepted May 29, 1989

Appendix 1. The exact locations of the type areas and sections and possible reference sections for the established stratigraphic units in the northeastern part of the Kainuu Schist Belt.

\section{Kurkikylä Group: type area; Kurkikylä, Suomussalmi, northern Finland}

Laanhongikko Fm: type section; map $353308 \mathrm{~B}, \mathrm{x}=7237.39, \mathrm{y}=560.43$, to the north $\left(350^{\circ}\right)$. reference locality; map $353305 \mathrm{~B}$, $\mathrm{x}=7235.60, \mathrm{y}=554.32$

Hetehongikko Mb: type section; map $353308 \mathrm{~B}, \mathrm{x}=7237.39, \mathrm{y}=560.43$, to the north $\left(350^{\circ}\right)$

Kivipuro Mb: type section; map $353308 \mathrm{~B}, \mathrm{x}=7237.55, \mathrm{y}=560.42$, to the north $\left(350^{\circ}\right)$

Rytiloma Mb: type localities; map $353308 \mathrm{~B}, \mathrm{x}=7237.70, \mathrm{y}=559.85 ; \mathrm{x}=7237.86, \mathrm{y}=560.42$

Kaaperinsuo Mb: type section; map $353308 \mathrm{~B}, \mathrm{x}=7237.59, \mathrm{y}=560.20$, to the north $\left(350^{\circ}\right)$. reference localities; map $353305 \mathrm{~B}, \mathrm{x}=7235.60, \mathrm{y}=554.32$; map $353305 \mathrm{D}, \mathrm{x}=7235.69, \mathrm{y}=557.38$

Matinvaara Fm: type section; map $353305 \mathrm{D}, \mathrm{x}=7238.03, \mathrm{y}=558.69$, to the north $\left(010^{\circ}\right)$. reference localities; map $353305 \mathrm{D}$, $\mathrm{x}=7238.52, \mathrm{y}=559.33 ; \mathrm{x}=7237.80, \mathrm{y}=558.98$; map $353305 \mathrm{~B}, \mathrm{x}=7237.36, \mathrm{y}=551.97$

Ahven-Kivilampi Fm: type localities; map 3533 05D, $\mathrm{x}=7237.74, \mathrm{y}=558.95$; map $353308 \mathrm{~B}, \mathrm{x}=7237.78, \mathrm{y}=560.15$; map $353305 \mathrm{~B}, \mathrm{x}=7236.11, \mathrm{y}=553.60$

Havukkasuo Mb: type localities; map 3533 05D, $\mathrm{x}=7237.74, \mathrm{y}=558.95$; map $353308 \mathrm{~B}, \mathrm{x}=7237.78, \mathrm{y}=560.15$

Kalettomansuo Mb: type locality; map $353305 \mathrm{~B}, \mathrm{x}=7236.11, \mathrm{y}=553.60$

Korvuanjoki Group: type area; Paljakkavaara, Suomussalmi-Puolanka, northern Finland

Paljakkavaara Fm: type section; map $353305 \mathrm{~A}, \mathrm{x}=7234.61, \mathrm{y}=552.76$, to the south $\left(190^{\circ}\right)$. reference section; map $353305 \mathrm{~A}$, $\mathrm{x}=7234.40, \mathrm{y}=554.85$. to the southeast $\left(160^{\circ}\right)$. type locality; map $353302 \mathrm{D}, \mathrm{x}=7235.52, \mathrm{y}=546.87$

Kurkisuo Mb: type section; map $353305 \mathrm{~A}, \mathrm{x}=7234.61, \mathrm{y}=552.76$, to the south $\left(190^{\circ}\right)$. reference sections; map $353305 \mathrm{~A}$, $\mathrm{x}=7234.40, \mathrm{y}=554.85$, to the southeast $\left(160^{\circ}\right)$; map $353305 \mathrm{~A}, \mathrm{x}=7234.48, \mathrm{y}=553.38$, to the south $\left(193^{\circ}\right)$; map $353302 \mathrm{D}$, $\mathrm{x}=7236.20, \mathrm{y}=548.10$, to the southeast $\left(160^{\circ}\right)$. reference locality; map $353305 \mathrm{D}, \mathrm{x}=7235.22, \mathrm{y}=556.82$

Paljakantie Beds: Type locality: map 3533 05A, $\mathrm{x}=7234.60, \mathrm{y}=552.82$

Pöksäkallio Mb: type section; map $353305 \mathrm{~A}, \mathrm{x}=7234.51, \mathrm{y}=552.81$, to the south $\left(190^{\circ}\right)$; reference section; map $353302 \mathrm{C}$, $\mathrm{x}=7234.32, \mathrm{y}=549.74$, to the southwest $\left(235^{\circ}\right)$; reference localities; map $353305 \mathrm{~A}, \mathrm{x}=7234.58, \mathrm{y}=552.11$; map $353305 \mathrm{~A}$, $\mathrm{x}=7233.68, \mathrm{y}=551.32 ; \mathrm{x}=7233.65, \mathrm{y}=554.44$

Honka-Jylkky Mb: type locality; map $353302 \mathrm{D}, \mathrm{x}=7235.52, \mathrm{y}=546.87$. reference localities; map $353302 \mathrm{D}, \mathrm{x}=7235.73$, $\mathrm{y}=547.60$; map $353305 \mathrm{~A}, \mathrm{x}=7233.86, \mathrm{y}=550.49$ 
Lukkarinvaara Fm: type section; map $353301 \mathrm{~A}, \mathrm{x}=7220.91, \mathrm{y}=542.27$, to the west $\left(265^{\circ}\right)$. reference section; map $353301 \mathrm{~A}$, $\mathrm{x}=7221.99, \mathrm{y}=542.37$, to the west $\left(255^{\circ}\right)$. type locality; map $353301 \mathrm{~A}, \mathrm{x}=7222.81, \mathrm{y}=542.10$

Kivisuo Mb: type section; map $353301 \mathrm{~A}, \mathrm{x}=7220.91, \mathrm{y}=542.27$, to the west $\left(265^{\circ}\right)$. reference section; map $353301 \mathrm{~A}$, $\mathrm{x}=7221.99, \mathrm{y}=542.37$, to the west $\left(255^{\circ}\right)$

Iso-Lukkari Mb: type locality; map $353301 \mathrm{~A}, \mathrm{x}=7222.81, \mathrm{y}=542.10$

East Puolanka Group: type area; eastern hills of Puolanka, northern Finland

Kiskonkoski Fm: type section; map 3533 02D, $\mathrm{x}=7235.45, \mathrm{y}=546.79$, to the southeast $\left(145^{\circ}\right)$. reference localities; map $353302 C, x=7234.29, y=548.61 ; x=7233.97, y=548.78$

Nenäkangas Mb: type section; map $353302 \mathrm{D}, \mathrm{x}=7235.45, \mathrm{y}=546.79$, to the southeast $\left(145^{\circ}\right)$. reference locality; map $353302 \mathrm{C}, \mathrm{x}=7234.29, \mathrm{y}=548.61$

Jylkynsuo Bed: type locality: map $353302 \mathrm{D}, \mathrm{x}=7235.42, \mathrm{y}=546.82$

Paljakkaoja Mb: type section; map $353302 \mathrm{D}, \mathrm{x}=7235.42, \mathrm{y}=546.82$, to the southeast $\left(145^{\circ}\right)$. reference locality; map $353302 \mathrm{C}, \mathrm{x}=7233.97, \mathrm{y}=548.78$

Vuorivaara Fm: type section; map $353302 \mathrm{C}, \mathrm{x}=7231.54, \mathrm{y}=549.98$, to the northwest $\left(290^{\circ}\right)$. reference section; map $353302 \mathrm{C}, \mathrm{x}=7231.24, \mathrm{y}=549.80$, to the northwest $\left(300^{\circ}\right)$

Alakylä Fm: type locality; map $353302 \mathrm{C}, \mathrm{x}=7231.43, \mathrm{y}=546.47$

Kovasinvaara Fm: type section; map $353302 \mathrm{C}, \mathrm{x}=7231.33, \mathrm{y}=545.97$, to the west $\left(250^{\circ}\right)$. type localities; map $353302 \mathrm{C}$, $\mathrm{x}=7231.71, \mathrm{y}=545.30 ; \mathrm{x}=7230.79, \mathrm{y}=546.13$

Reikä-Äikkä Mb: type section; map $353302 \mathrm{C}, \mathrm{x}=7231.33, \mathrm{y}=545.97$, to the west $\left(250^{\circ}\right)$. reference section; map $353302 \mathrm{C}$, $\mathrm{x}=7231.28, \mathrm{y}=546.16$, to the southwest $\left(220^{\circ}\right)$

Korpijoki Mb: type section; map $353302 \mathrm{C}, \mathrm{x}=7231.31, \mathrm{y}=545.92$, to the west $\left(250^{\circ}\right)$. type locality; map $353302 \mathrm{C}$, $\mathrm{x}=7231.58, \mathrm{y}=545.25$

Pikku-Äikkä Mb: type localities; map 3533 02C, $\mathrm{x}=7231.71, \mathrm{y}=543.30 ; \mathrm{x}=7230.79, \mathrm{y}=546.13$; map $353301 \mathrm{D}$, $\mathrm{x}=7228.62, \mathrm{y}=546.89$. reference section; map $353301 \mathrm{D}, \mathrm{x}=7228.88, \mathrm{y}=546.72$, to the west $\left(260^{\circ}\right)$

Kometto Fm: type sections; map $353301 \mathrm{D}, \mathrm{x}=7229.07, \mathrm{y}=546.43$, to the west $\left(256^{\circ}\right) ; \mathrm{x}=7229.29, \mathrm{y}=545.88$, to the southwest $\left(235^{\circ}\right) ; \mathrm{x}=7229.30, \mathrm{y}=545.80$, to the southwest $\left(245^{\circ}\right) ; \mathrm{x}=7229.68, \mathrm{y}=545.68$, to the southwest $\left(245^{\circ}\right)$. reference sections; map $353301 \mathrm{~A}, \mathrm{x}=7222.29, \mathrm{y}=544.92$, to the northwest $\left(315^{\circ}\right)$; map $353301 \mathrm{D}, \mathrm{x}=7229.54, \mathrm{y}=545.71$, to the southwest $\left(230^{\circ}\right)$

Hallakulma Fm: type section; map $353301 \mathrm{C}, \mathrm{x}=7221.89, \mathrm{y}=545.01$, to the south $\left(200^{\circ}\right)$. reference section; $353301 \mathrm{~A}$, $\mathrm{x}=7222.29, \mathrm{y}=544.89$, to the northwest $\left(315^{\circ}\right)$

Nuottilampi Mb: type section; map $353301 \mathrm{C}, \mathrm{x}=7221.89, \mathrm{y}=545.01$, to the south $\left(200^{\circ}\right)$. reference section; map $353301 \mathrm{~A}$, $\mathrm{x}=7222.29, \mathrm{y}=544.89$, to the northwest $\left(315^{\circ}\right)$

Pentinsuo Mb: type section; map $353301 \mathrm{~A}, \mathrm{x}=7221.75, \mathrm{y}=544.84$, to the south $\left(200^{\circ}\right)$. reference locality; map $353301 \mathrm{~A}$, $\mathrm{x}=7221.60, \mathrm{y}=544.92$

Siikavaara Fm: type section; map $353301 \mathrm{D}, \mathrm{x}=7228.56, \mathrm{y}=545.30$, to the west $\left(255^{\circ}\right)$ 